\title{
Struggling around the "natural" divide: The protection of tangible and intangible indigenous property
}

\author{
Emanuela Arezzo
}

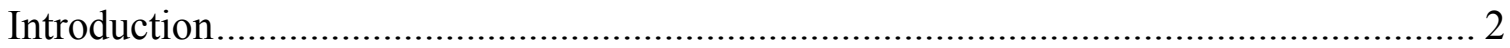

1. Traditional knowledge and biodiversity: conceptual framework ................................. 3

1.1. Traditional knowledge and its economic value in market economies ..................... 4

1.2. The stringent bond between traditional knowledge and biodiversity ...................... 6

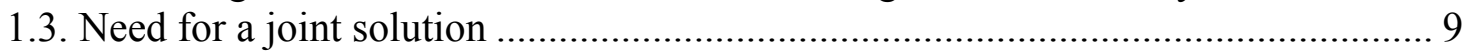

2. The normative international framework for the protection of biodiversity and the protection of traditional knowledge ............................................................................ 10

3 . The disclosure of origin of the source of genetic resources and traditional knowledge as a possible way to comply with CBD's obligations..................................................... 14

3.1. Introducing the disclosure of origin of genetic resources within the Patent

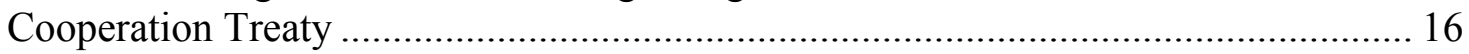

3.2. A second proposal advanced by southern Developing Countries........................... 19

3.3. The Position of the European Union................................................................... 21

4. Why a defensive mechanism by itself is not sufficient............................................ 24

5. Towards a fair and equitable sharing of the benefits associated to biodiversity and

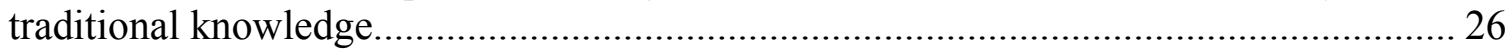

6. Crafting some sort of entitlement for traditional knowledge owners .......................... 28

6.1. Liability rules for indigenous communities? Pros and cons ................................. 28 6.2. The document drafted by the WIPO Intergovernmental Committee on Intellectual Property and Genetic Resources, Traditional Knowledge and Folklore........................ 33

7. A colonialist model of intellectual property?............................................................... 36 7.1. Alleged barriers to create an entitlement to intangible TK associated to biological

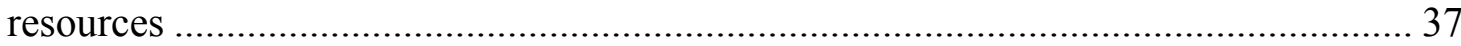

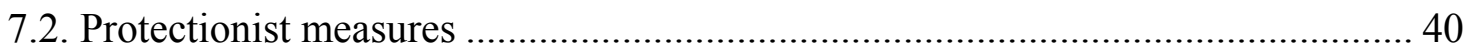

8. Downsides of the colonialist approach and possible ways out ................................... 43

8.1. The adoption of a misappropriation regime...................................................... 45

8.1.1. Misappropriation in the form of a negative entitlement and its advantages over

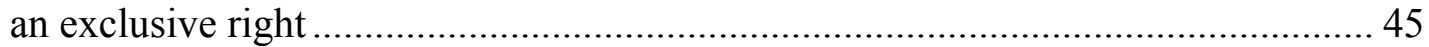

8.1.2. Commonalities and differences with the Compensatory Liability Regime.... 46

8.1.3. Implementation measures and legal status of the misappropriation regime ... 49

8.2. Traditional knowledge and open source, why not? ............................................... 51

8.3. Misappropriation right and the anticommons over genetic resources ................... 52

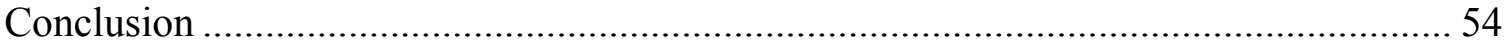




\title{
Struggling around the "natural" divide: The protection of tangible and intangible indigenous property
}

\author{
Emanuela Arezzo(*)
}

\section{Introduction}

In a century where access to information represents the key to doing business, big companies have come to realize that poor Developing Countries ${ }^{1}$, whose economies are still mainly based on agriculture and textiles, have an invaluable treasure worth billions of dollars. The varieties of plants and trees, located mostly in the Southern areas of the hemisphere, amount to a huge collection of genetic material with countless potential applications. Moreover, the value of these vast collections is further increased by the circumstance that local communities living in these areas have long studied and experimented with the medicinal - as well other scientific - properties of such plants and herbs. Sometimes shamanic knowledge, for example, has reached very precise and effective results in the curing of some diseases.

While indigenous communities have their own legal systems and mores regulating the way their resources, both tangible and intangible, are to be produced and enjoyed within the group, Developed Countries often look at traditional knowledge through the lenses of modern intellectual property systems. They reason in terms of inventiveness and novelty, they look for a specific author/inventor to reward and when they do not find any of the

(*) Emanuela Arezzo is Doctor in Law and Economics; research fellow in Intellectual Property and Antitrust Law at LUISS University, Rome; and S.J.D. Candidate at Duke Law School, Durham NC, USA. I would like to thank professors Gustavo Ghidini, Jerome H. Reichman and James Thomas for comments on previous draft of this contribution. I also would like to thank the invaluable help of the editors of this Journal. Any errors or imprecision is solely attributable to myself.

${ }^{1}$ I would like to point out that the term "Developing Countries" is also intended to comprehend the group of so called "Least-Developing Countries" (LDCs), as elected by the United Nations. More information on the status of DCs as well as LDCs can be found at the official World Trade Organization (WTO) website, and especially at http://www.wto.org/english/tratop_e/devel_e/d1who_e.htm. 
above, they just assume they have the right to take indigenous countries' scientific knowledge without giving anything in return. Such knowledge, they claim, is in the public domain.

This contribution is aimed at analyzing the current normative framework as well as the international debate surrounding the protection of biodiversity and traditional knowledge in such a way to provide some critical thoughts and ideas for a tentative solution of the problem. In particular, after a comprehensive review of the international legal framework and of the on-going proposals currently discussed in several international fora, the work discusses the likely implementation of a misappropriation system, shaped like a sort of negative entitlement which would give TK-owners protection only against illicit misuse or misappropriation of their TK. Such a system, together with some amendments of current national and international patent laws, might provide the adequate level of protection that satisfy the interests of TK holders and of foreign companies who needs access to such tangible and intangible resources to foster scientific progress.

\section{Traditional knowledge and biodiversity: conceptual framework}

The beneficial properties of the Azadirachta Indica, commonly known as the Indian neem tree, have been known and employed by Indian farmers for centuries and yet only a few decades ago they have attracted the interests of foreign biotech and pharma companies. At the beginning of the seventies many biologists and etnobotanists moved to India to investigate the neem tree's attributes. They observed and studied the ways local people utilized the tree for a long time and the fruits of their work, entirely based on local genetic heritage species and knowledge, has led to the patenting of a range of products, 
from pesticides to toothpaste. Needless to say, not a single penny went to Indian farmers or to the Indian Government ${ }^{2}$.

The neem tree is probably the most well-known case of biopiracy - better defined as biosquatting $^{3}$-- but unfortunately is not the only one ${ }^{4}$. Western companies have recently come to understand the immeasurable value of the biodiversity that indigenous communities, mainly located in Developing Countries, have carefully studied and cherished across centuries ${ }^{5}$. Moreover, they have come to acknowledge the value of the so called traditional knowledge associated with it.

\subsection{Traditional knowledge and its economic value in market economies}

The term "traditional knowledge" (hereinafter also "TK") has been the subject of many conceptualizations. Usually, scholars employ the term generally to cover a broad range of "indigenous subject matters", ranging from folklore to shamanic knowledge.

\footnotetext{
${ }^{2}$ For a complete overview of the story see V. Sheva, Neem Tree: a case history of biopiracy, available at http://www.twnside.org.sg/title/pir-ch.htm.

${ }^{3}$ The term "biosquatting" seems to be better suited then "biopiracy" to indicate the misappropriation of "intangible components of genetic sources and/or traditional knowledge that could be in the public domain as well as the unauthorized claiming of traditional knowledge that is in control of indigenous people and local communities". See N. Pires de Carvalho, From the Shaman's Hut to the Patent Office: in Search of a TRIPS-Consistent Requirement to Disclose the Origin of Genetic Resources and Prior Informed Consent, 17 WASH. U. J.L. \& POL'Y 111, 2005.

${ }^{4}$ For other famous examples, see the "turmeric patent" case and the "quinoa patent" case, in G. Dutfield, Intellectual Property Rights, Trade and Biodiversity: Seeds and Plant Varieties, 1999. In a recent report Jay McGown provides an extremely long and detailed list of African genetic resources misappropriated by foreign investors with no proof whatsoever that any of the huge profits these companies made has been passed on local population. See J. McGown, Out of Africa: the Mysteries of Access and Benefits Sharing, the Edmonds Institute and the African Centre for Biosafety, January 2006, available at http://www.edmonds-institute.org/outofafrica.pdf.

${ }^{5}$ Specifically, we will use the term "biodiversity" as a broad concept comprehending both "biological diversity" and "biological resources", as described in the Convention on Biological Diversity (CBD). The CBD is an agreement promulgated by the United Nations within the 1992 Earth Summit held in Rio de Janeiro. As we will see infra at para. 2, the CBD has three main goals: the preservation of biological diversity, the sustainable use of its components, and the fair and equitable sharing of the benefits accruing from the use of the genetic resources.

The CBD, indeed, describes biological diversity as "the variability among living organism from all source including, inter alia, terrestrial, marine and other aquatic ecosystems and the ecological complexes of which they are parts"; and describes the biological resources as "[...] genetic resources, organisms or parts thereof, populations, or any other biotic component of ecosystems with actual or potential use or value for humanity". Convention on Biological Diversity, (CBD), done at Rio de Janeiro, Brazil, 5 June 1992, art. 2.
} 
Traditional knowledge is usually characterized by peculiar features like its joint creation by and its continuous sharing within the members of local communities. Such knowledge is the fruit of an intergenerational process whereby generations of people pass one another their cultural heritage and the latter grows, therefore, as time passes ${ }^{6}$. Another significant feature of traditional knowledge is its "unfixed" character". Shamanic knowledge, rituals, dances, songs are often handed down orally. As there is no fear of stealing such knowledge or need to trade it within the indigenous communities, local people have not felt the need to codify it in a written form ${ }^{8}$.

However, for the purposes of this work, a distinction needs to be made between so called traditional knowledge stricto sensu vis-à-vis expressions of traditional knowledge, like "traditional cultural expressions" ("TCEs") and expressions of folklore. The World Intellectual Property Organization (WIPO) Secretariat has rightly pointed out that the latter category shows close similarity with copyrightable subject matter (i.e. copyright, performers' rights, design rights), while the former bears close resemblance to industrial property (not just with patents but also trade secrets and know-how). Although the

\footnotetext{
${ }^{6}$ See the definition provided by Johnson who depicts TK as a "body of knowledge built by a group of people through generations living in close contact with nature. It includes a system of classification, a set of empirical observations about the local environment, and a system of self management that governs resource use". M. Johnson, Research on Traditional Environmental Knowledge: its Development and its Role, in LORE: CAPTURING TRADITIONAL ENVIRONMENTAL KNOWLEDGE, 3, 3-4, IDRC, 1002.

${ }^{7}$ Generally on the description of traditional knowledge's features see: G. Dutfield, TRIPS-Related Aspects of Traditional Knowledge, 33 CASE W. RES. J. INT'L L. 233 (2001), J. Koopman, Bumps and Bends in the Road to Intellectual Property for Traditional Knowledge, InTElleCtUAL ProperTy LAW 2004, MolengRAFICA, edited by F. W. Grosheide \& J.J. Brinkhof, Antwerpen, 2004.

${ }^{8}$ Indeed, as well known, in patent law, the requirements of written description and the enablement serve the purpose of solving the so-called Arrow's paradox. Indeed, the once the contours of the inventive concept are formally embedded in the title of protection, the inventor can trade her knowledge in the market without fearing that the latter be stolen by a third party who, in turn, might claim to be the owner. [K.J. Arrow, Economic Welfare and the Allocation of Resources for Invention, in R.R. Nelson (ed.), THE RATE AND DiRECTION OF INVENTIVE ACTIVITY, 609-625 (1962)]. Likewise, in copyright law the requirement of fixation, which has - at least in American law - a constitutional value, is aimed at proving that the work has been effectively created and is fundamental to attribute the creation to the author and reward him with the exclusive right.
} 
Secretariat admits that the different forms of TK can sometimes overlap, it defines TK stricto sensu as "ideas developed by traditional communities and indigenous people, in a traditional and informal way, as a response to the needs imposed by their physical and cultural environments [...]" and adds that "those ideas contrast with the respective expressions, such as folk tales, poetry, and riddles, folk songs and instrumental music, dances, plays, etc" 9 .

The analysis of issues relating to folklore and cultural intangible heritage in general lies outside the scope of this paper. I will analyze the traditional knowledge stricto sensu, specifically referring to medical and "scientific" knowledge associated to germ plasm and biodiversity. Moreover, because the purpose of this work is to find a balanced way to protect indigenous communities' economic interests against unfair conducts and misappropriations from Developed Countries' enterprises, we cannot analyze the issue of traditional knowledge protection without taking into consideration the related question of biodiversity.

\subsection{The stringent bond between traditional knowledge and biodiversity}

Although it is important to stress that biodiversity and traditional knowledge are separate concepts $^{10}$, they always go hand in hand. Indeed biopiracy cases usually involve the misappropriation of both genetic resources and associated traditional knowledge. The plant and animal varieties present in Brazil, in Peru or in Australia have come to represent a treasure of immeasurable value in terms of a genetic heritage of billions of compounds whose practical application might be countless. However, because of such

\footnotetext{
9 See Wipo document WIPO/GRTKF/IC/5/7, available at http://www.wipo.int/documents/en/meetings/2003/igc/pdf/grtkf_ic 5 7.pdf.

${ }^{10} \mathrm{G}$. Van Overwalle, Protecting and sharing biodiversity and traditional knowledge: Holder and user tools, 53 ECOLOGICAL ECONOMICS 585 (2005) 585.
} 
huge quantity the screening process of them all would be extremely time-consuming and costly. The role of traditional and shamanic knowledge is therefore crucial to knock down these search costs and drive researchers right through toward the most promising paths. Lacking traditional knowledge, there is the risk that the biodiversity long cherished by Developing Countries would not be investigated and studied; or, in the best case scenario, biotech companies would need a huge amount of time and resources to get to some useful applications $^{11}$. As in the case of small molecules ${ }^{12}$, big biotech and pharma companies are unwilling to invest huge capitals in research projects whose outcome is severely uncertain. From this viewpoint, traditional knowledge solves a market failure problem providing incentives to invest in the form of potential paths of research. Furthermore, as long as these companies do not reward anyone for their production, and hence do not bear any cost for it, traditional knowledge represents a positive externality. One could wonder where is the problem? Indigenous people's creation of traditional knowledge is not moved by the typical monetary incentives of a market economy; they do not aim at obtaining exclusive rights to exploit their innovations. The problem, however, does exist and it bears several implications. Beyond the serious environmental risks connected with an unregulated and unmonitored taking of the natural resources, traditional knowledge owners are not rewarded for their intellectual labor nor are their governments compensated for the expropriation of their tangible properties. Furthermore because, as

\footnotetext{
${ }^{11}$ In a recent article Professor McManis has carefully reported the results of a joint research project between the Aguaruna people of Peru and three American universities (so called ICBG-Peru Project). The report clearly recognizes the critical role played by Aguaruna's traditional knowledge to identify antimalarial species and states that lacking such knowledge it would have taken at least decades to achieve the same results. See, C. McManis, Intellectual Property, Genetic Resources and Traditional Knowledge Protection: Thinking Globally, Acting Locally, 11 CARDOZO J. INT’L \& COMP. L. 547 (2003-2004).

${ }^{12}$ See, J. H. Reichman, A.K. Rai, P. Uhlir, C. Crossman, Pathways Across the "Valley of Death:" Novel Intellectual Property Strategies to Solve the Small Molecule Puzzle, forthcoming 2006, article on file with the author.
} 
Professor Boyle has carefully pointed out ${ }^{13}$, traditional knowledge and folklore flow out of Developing Countries free of legal constraints and tend to go back embedded in foreign patents, there is a strong risk that indigenous people lose the possibility to keep using their collective knowledge. ${ }^{14}$

It has been correctly pointed out that the issue regarding the protection of biodiversity and related traditional knowledge presents once again a conflict of interests between Northern (Developed) and Southern (often Developing) countries of the World; the former technology-rich industrialized countries, located primarily in the zone of the Northern Hemisphere, and the biodiversity-rich Developing Countries, located primarily in the tropics and Southern Hemisphere ${ }^{15}$. The cooperation between these two groups of countries could bring about significant innovations in a variety of products, ranging from drugs to agricultural products, to cosmetics etc. However, only rarely has this cooperation resulted in revenues for Developing Countries. In the best case scenario, the unequal bargaining power of the contracting parties leads to biased licensing schemes whereby indigenous communities are only rewarded for the biodiversity they provide, but they are not compensated for the intellectual labor surrounding such tangible resources; also, they

\footnotetext{
13 "[...] Curare, batik, myths, and the dance "lambada" flow out of Developing Countries, unprotected by intellectual property rights, while Prozac, Levis, Grisham [...] flow in protected by a suite of intellectual property laws which in turn are backed by the threat of trade sanctions". See J. Boyle, Shamans, SOFTWARE AND SPLEENS: LAW AND THE CONSTRUCTION OF THE INFORMATION SOCIETY, Harvard University Press, Cambridge (MA), 1996, at 125.

${ }^{14}$ This assumption lies on the fact that (almost) all DCs are WTO Members, hence they have adhered to the Agreement on Trade-Related Aspects of Intellectual Property Rights (TRIPS), signed in Marrakesh, Morocco on 15 April 1994. As I have better explained infra at footnote 86, Least Developing Countries (LDCs) will have to comply with TRIPS by 2016.

${ }^{15}$ C.R. McManis, The Interface Between International Intellectual Property and Environmental Protection: Biodiversity and Biotechnology, in 76 WASH. U. L. QUARTERLY, 255, (1998).
} 
are excluded from any forms of participation in the results of the subsequent researches conducted on biodiversity. Often such agreements do not take place at all ${ }^{16}$.

\subsection{Need for a joint solution}

As hinted earlier on, there is always a the bond between traditional knowledge and genetic resources, although it can be more or less apparent to the scientist. There are cases where the two are extremely intertwined. This happens when the compound contained in a plant, for example, is immediately effective -- as it is -- to cure the symptoms of a certain disease. There are other cases where the link between the two is not apparent, but indigenous people have discovered the process to apply the genetic resource in such a way to obtain a certain result. In still other cases, the indigenous knowledge amounts to a lead towards potential applications of the genetic material. In the first case and the second case, all foreign companies have to do is to isolate the molecule and then file for a patent. In the second case, foreign scientists have more work to do, depending on how advanced the local practice was.

One might observe that notwithstanding the close link between the two, biodiversity and traditional knowledge should -- at least in principle -- differ for a simple reason: the former is indeed material while the latter, as all kinds of knowledge, is abstract and intangible. The biodiversity resources, however, represent a very peculiar case. For the purpose of our analysis, genetic biological resources, like all genetic resources, represent a set of codes, each piece carrying specific information that deals with a certain function.

\footnotetext{
${ }^{16}$ There are plenty of examples of local communities that are constantly ripped off their biological heritage and there have been cases where Developing Countries, incapable of trading their own biodiversity, and have blown up their natural resource to feed their own people. For example, Madagascar appears to be one of the richest countries in terms of biodiversity (it should have about the 5\% of the world's species) but it has blow up most of its forests to feed its people. J. Boyle, SHAMANS, SOFTWARE AND SPLEENS: LAW AND THE CONSTRUCTION OF THE INFORMATION SOCIETY, p.128.
} 
Once the relation between a portion of code and its function has been revealed, the genetic resource acquires value. ${ }^{17}$ Conversely, TK has value only with connection to that specific genetic resource.

Nowadays, whenever biodiversity is transferred - and not just stolen - parties' unequal bargaining powers lead to unfair licensing agreements where companies compensate local communities only for the biogenetic resources, through lump sums or royalties ${ }^{18}$. Although a few examples do exist about contractual scheme envisioning sort of "grant back" provisions or grant non-exclusive license for "research use" on foreign companies (derivative) innovations based on TK, these are quite rare and surely stand far from everyday reality ${ }^{19}$.

\section{The normative international framework for the protection of biodiversity and the protection of traditional knowledge}

The need to spur cooperation between Northern and Southern countries is well reflected in the provisions of the Convention on Biological Diversity (hereinafter "the Convention" or simply $\mathrm{CBD})^{20}$. The Convention, promoted by the United Nations, recognizes the value of biodiversity as world heritage and stresses the need that all Contracting Parties, no matter if holders or not of such heritage ${ }^{21}$, enact measures aimed at protecting and

\footnotetext{
${ }^{17}$ Although, in theory, biodiversity could be stolen even in its raw state for the search costs described above it is unlikely that pharma will just take hundreds of samples to screen without any idea of the likely peculiarities of the genetic resources.

${ }^{18}$ G. Ghidini, Equitable sharing of Benefits from Biodiversity-Based Innovation: Some Reflections under the Shadow of a Neem Tree, in InTERnational Public GoOds AND TRANSFER Of TeChNOLOGY Under A Globalized InTELlectual Property Regime, edited by J.H. Reichman and K. Maskus, Cambridge MA, 2005.

${ }^{19}$ Professor McManis praises the way the aforementioned ICBG-Peru Project was shaped in terms of guarantees and safeguards afforded to the Peruvian community, but this is the only example found so far.

${ }^{20}$ Convention on Biodiversity (CBD), see supra footnote 5 .

${ }^{21}$ Recall, indeed, that some countries are holders ex situ of genetic resources, like many European Countries where botanic gardens and big depositories of genetic resources are located. Those countries similarly share the duty to preserve and conserve biodiversity.
} 
safeguarding such inheritance. The Convention aims at spurring the aforementioned cooperation while preserving the general and globally shared interest towards the preservation of biodiversity and the diverse interests of Contracting Parties.

I would like to conceptually dissect the Convention in three subsections. The first set of provisions impose on all Contracting Parties a set of duties to promote sustainable uses and conservation (in-situ and ex-situ ${ }^{22}$ ) of biological resources and encourages them to "create conditions to facilitate access to genetic resources for environmentally sound uses" (emphasis added) ${ }^{23}$. A second set of norms recognize States' sovereignty over natural resources and their right to give access to third parties ${ }^{24}$. Therefore, although the Convention clearly aims at encouraging the sharing of biological resources, it firmly recognizes States' prerogatives and to that goal it further establishes that access to genetic sources must be subject to prior informed consent (PIC) of the party providing such resources; once consent has been given, terms of access must be mutually agreed ${ }^{25}$. Last, the Convention promotes "the fair and equitable sharing of the benefits arising from the utilization of genetic resources" 26 . Specifically, the Convention establishes that each Contracting Party shall take appropriate measures in order to afford (to the party providing the biological resources) equitable sharing of: the results of research and development, and the benefits arising from the commercial and other utilization of genetic resources. $^{27}$

\footnotetext{
${ }^{22}$ Ibidem, arts 6, 8 and 9.

${ }^{23}$ Ibidem, art. 15.2.

${ }^{24}$ Ibidem, art. 15.1 .

${ }^{25}$ Ibidem, arts $15.5,15.4$.

${ }^{26}$ Ibidem, arts. 1, 8(j), 15.7, 19.2. The principle is also supported by the FAO International Treaty on Plant and Genetic Resources for Food and Agriculture, adopted with Resolution 3/2001, in November 2001 (art. 9 - Farmers' Rights, para. 2, b). See M. Blakeney, Protection of Plant Varieties and Farmers' Rights, 2002 E.I.P.R., 9.; see also EC Directive 98/44, above n. 2 (Preamble, recitals 56 and 11).

${ }^{27} \mathrm{CBD}$, art. 15.7. The article further specifies that "Such sharing shall be upon mutually agreed terms".
} 
While the Convention rightly devotes a huge deal of attention to the issue of access to genetic biological resources, it affords much less consideration to the equally important matter of traditional (medical) knowledge associated with biological resources. In fact, the promotion of innovation and practices based on traditional knowledge and the sharing of the benefits arising from its utilization is expressly envisaged - within the Convention -- as instrumental to promote in-situ conservation of biological resources ${ }^{28}$. However, the concern for traditional knowledge, innovations and practices of indigenous and local communities, inter alia, has led to the creation, by the Conference of the Parties (hereinafter: $\mathrm{CoP}$ ), the very same governmental body of the Convention, of a Working Group to specifically address the implementation of the art. $8(\mathrm{j}) \mathrm{CBD}^{29}$, and later on to the adoption of the Bonn Guidelines on Access to Genetic Resources and Fair and Equitable Sharing of the Benefits Arising out of their Utilization, approved by decision VI/24 of the Conference of the Parties in $2002^{30}$. The Guidelines are meant to provide a set of voluntary inputs for Contracting Parties involved in the process of drafting legislative, administrative or policy measures on access and benefits sharing (ABS) provisions set forth by the CBD, in particular articles 8(j), 10(c), 15, 16 and 19.

Among the most relevant provisions, the Guidelines strengthen the importance of prior informed consent (PIC) as a means to prevent misappropriation of genetic resources. To this regard, the Guidelines establish that the PIC should be granted for certain specific

${ }^{28}$ The Convention establishes at article 8(j) that Contracting Parties shall: "subject to its national legislation, respect, preserve and maintain knowledge, innovation and practices of indigenous and local communities [...] and promote with the approval and involvement of the holders of such knowledge, innovations and practices and encourage the equitable sharing of the benefits arising from the utilization of such knowledge, innovation and practices" (emphasis supplied). It is interesting noting that this provision does not compel countries to enact new legislation to pursue the goals outlined above (as it does in most of the other provisions).

${ }^{29}$ Information can be found at http://www.biodiv.org/programmes/socio-eco/traditional/default.asp.

${ }^{30} \mathrm{~A}$ copy of the Bonn Guidelines can be found at http://www.biodiv.org/decisions/?lg=0\&dec=VI/24. 
uses of the biodiversity provided; that any change of such use should prompt a new application for PIC; and that competent local authorities could be involved in the mechanism of PIC certification, for example by handling the applications for access. The guidelines also deal with some aspects of the role of intellectual property in the access and benefit sharing process, proposing the disclosure of the country of origin of genetic resources in (patent) applications as a possible means to track compliance with PIC.

Notwithstanding the relevance of the principles set forth in the Convention, the international scenario on the protection of biodiversity still seems dubious and uncertain. On the one side, harmonization on the international level remains far away. Although Contracting Parties do have a legal obligation to comply with CBD provisions, the CBD has not been ratified by some of the most economically significant countries, like the United States of America ${ }^{31}$. And even the same Bonn Guidelines, promoted by the CoP, are not mandatory for Contracting Parties to implement. On the other side, the international status of the Convention, outside the realm of WTO (and TRIPS ${ }^{32}$ ), makes its practical enforcement hard, if not impossible. ${ }^{33}$

The necessity of reconciling the provisions set forth in the CBD and the TRIPS Agreement has been acknowledged during the Doha Declaration where the TRIPS Council has been appointed to examine, inter alia, the relationship between the TRIPS Agreement and the CBD, and the protection of traditional knowledge and folklore ${ }^{34}$.

\footnotetext{
${ }^{31}$ The United States of America signed the Convention on June 1993 but they did not ratify it. The complete list of adhering countries can be found at http://www.biodiv.org/world/parties.asp.

${ }^{32}$ See supra footnote 14.

${ }^{33}$ This is expressly recognized in a document presented by a group of countries (namely: Bolivia, Brazil, Colombia, Cuba, India and Pakistan), IP/C/W/459, which I will discuss later on in this article.

${ }^{34}$ Ministerial Declaration, adopted on $14^{\text {th }}$ November 2001, WT/MIN(01)/DEC/1, para. 19 (available at http://www.wto.org/English/thewto_e/minist_e/min01_e/mindecl_e.htm) instructing the TRIPS Council to
} 
Several proposals are currently being discussed in order to bring into effect the provisions set forth in the Convention. An ad hoc Committee has been created within WIPO to address issues relating traditional knowledge and folklore ${ }^{35}$. Besides the proposal advanced in that forum, others have been suggested within the Conference of the Parties. $^{36}$ Others have come from academics and eminent scholars. In the following section, I will examine some of these on-going proposals which have been presented to comply with the provisions of CBD.

\section{The disclosure of origin of the source of genetic resources and traditional knowledge as a possible way to comply with CBD's obligations}

Many countries have repeatedly proposed, at different lengths, the amendment of international patent treaties and corresponding domestic law in order to introduce the mandatory disclosure of the origin of genetic resources and traditional knowledge in patent applications.

The employment of biodiversity is rarely recognizable by merely looking at the final product and not even through an accurate analysis could indigenous people find out when biological resources have been taken without PIC, not to mention ABS. The same applies for traditional knowledge. When the invention consists of the very same use of the plant

examine the relationship between the TRIPS Agreement and the CBD, particularly in lights of arts. 7 and 8 TRIPS. See generally, G. Dutfield, InTEllectual Property Rights TRADE AND Biodiversity, London, chapters 3-6, (2000).

${ }^{35}$ In October 2000 WIPO created an Intergovernmental Committee on Intellectual Property and Genetic Resources, Traditional Knowledge and Folklore which was meant to create an international forum for discussion concerning the interplay between intellectual property rights and the issues of traditional knowledge, genetic resources and expression of folklore and cultural indigenous knowledge. Moreover, the just mentioned issues have also been discussed within another WIPO working group: the working group on reform of the Patent Cooperation Treaty.

${ }^{36}$ The documents of the eight ordinary meeting organized by the Conference of the Parties to the CBD held in Brazil at the end of March 2006 can be found at http://www.biodiv.org/doc/meeting.asp?lg=0\&mtg=cop08. 
to solve a certain technical problem the link between the biological resource and the patent is apparent; nonetheless, sometimes traditional scientific knowledge only provides lead time advantage in the form of useful leads that bioprospectors use to screen only certain plants over others. The isolated molecules and compounds can then show other extra properties (beside the ones identified by indigenous communities) or the same properties can be studied and implemented for other purposes. In the latter case, the link between TK and final product blurs along the way towards patent offices and indigenous people will not be able to find out about - and hence to oppose efficiently to -biosquattings ${ }^{37}$.

The introduction of the disclosure (of origin) requirement would increase transparency and help Developing Countries in monitoring the actual compliance to the provisions set forth in the Convention regarding PIC and the sharing of the results and the benefits at large flowing from the utilization of tangible and intangible indigenous resources. The implementation of such requirement at a supranational level appears fundamental because, as it has been rightly observed, biodiversity and related TK are employed by biotech and pharma companies to satisfy the demand of their own markets ${ }^{38}$. Chances are that final products will be mostly - if not entirely -- commercialized in rich Developed Countries - think for example about cosmetics based on aloe vera. Therefore, even though the requirement has been implemented -- to different extents -- by several

\footnotetext{
${ }^{37}$ This is confirmed by a recent Communication (document IP/C/W/458, November $5^{\text {th }} 2005$ ) where Peru was lamenting difficulties in screening Japanese patent applications to filter out patents that might be based on traditional knowledge.

${ }^{38}$ This point is clearly stressed in a document proposed by a group of Developing Countries where they argue that: "[...] biopiracy is a global problem and [...] involves the acquisition of material in one country and seeking of a patent in another country. This means that relying on national measures alone is not sufficient to address the biopiracy problem". See document IP/C/W/429/Rev.1., para. 17. I will analyze this document in detail in following para. 3.2.
} 
contracting parties of the $\mathrm{CBD}^{39}$, mostly Developing Countries, it is fundamental for the latter that Developed Countries implement it first.

\subsection{Introducing the disclosure of origin of genetic resources within the Patent}

\section{Cooperation Treaty}

As hinted above, many negotiations are taking places in different fora at the moment. In the last session of the working group on the reform of the Patent Cooperation Treaty (PCT) held within WIPO, Switzerland has recently reiterated its proposal to amend some of the rules accompanying the PCT in order to allow national patent systems to require the disclosure of source of origin of both genetic resources and related traditional knowledge ${ }^{40}$. Swiss delegates have presented the same proposal to the "Ad Hoc OpenEnded Working Group on Access and Benefit-Sharing” organized by the Conference of the Parties of the $\mathrm{CBD}^{41}$.

\footnotetext{
${ }^{39}$ Understandably, many Developing Countries (Bolivia, Colombia, Costa Rica, Ecuador, Egypt, India, Peru, and Venezuela) have amended their patent law in such a way to establish the requirement as a patentability element. Other countries, like the European Community' Members have included the requirement only as recommendation (see in more details at para. 3.3). Eventually, some other countries have restricted the application of the requirement only to some subject matters (like Egypt and India where it can only apply to patent law). For more detailed information see N. Pires De Carvalho, From the Shaman's Hut to the Patent Office, p. 123 and ff.

${ }^{40}$ See Proposals by Switzerland Regarding the Declaration of the Source of Genetic Resources and Traditional Knowledge in Patent Applications, WIPO documents PCT/R/WG/4/13 and, with identical contents, PCT/R/WG/5/11 Rev., available at www.wipo.int/pct/en/meetings/reform_wg/pdf/pct_r_wg_5_11_rev.pdf. Also see the recent document: Further Observations by Switzerland on Its Proposals Regarding the Declaration of the Source of Genetic Resources and Traditional Knowledge in Patent Applications, WIPO document PCT/R/WG/7/9, available at www.wipo.int/edocs/mdocs/pct/en/pct_r_wg_7/pct_r_wg 7 9.doc.

The content of these documents have been summarized in document: PCT/R/WG/8/7, presented at the eighth session of the working group on the reform of the PCT. Such document is the most updated in circulation so far. In fact, the nineth session of the working group on the reform of the PCT has taken place in October 2006, but unfortunately, at the moment this contribution has been completed, no documents were published on the WIPO website yet. More information can be found at http://www.wipo.int/pct/reform/en/.

41 "Measures to support compliance with prior informed consent of the contracting party providing genetic resources and mutually agreed terms on which access was granted in contracting parties with users of such resources under their jurisdiction", document UNEP/CBD/WG-ABS/4/INF/12, 17 January 2006, available at www.biodiv.org/doc/meetings/abs/abswg-04/information/abswg-04-inf-12-en.doc.
} 
As explained by Swiss delegates, the proposal is aimed at satisfying the so called "four Ts": a) transparency, as the disclosure obligation within the patent system would surely increase transparency in access and benefit sharing with regard to genetic resources and traditional knowledge; b) traceability, as such obligation would facilitate providers of genetic resources and traditional knowledge in keeping track of the use of their tangible and intangible resources as well as the development resulting in patentable inventions; c) technical prior art, as the disclosure obligation would also assist patent examiners and judges in the establishment of prior art with regard to inventions that somehow relate to genetic resources and related TK; and, d) mutual trust, as the disclosure of the source of origin would increase mutual trust among the various stakeholders involved in access and benefit sharing. ${ }^{42}$

In practice, the core of the proposal concern the insertion of a new provision to rule 51bis(1), allowing national patent law to be modified in such a way to require applicants to furnish: "(i) a declaration as to the source of a specific genetic resource to which the inventor has had access, if the invention is directly based on such a resource ${ }^{43}$; and (ii) a declaration as to the source of traditional knowledge related to genetic resources, if the inventor knows that the invention is directly based on such knowledge",44 45 . The proposal

\footnotetext{
The same proposal had been presented for informational purposes to the to the WIPO Intergovernmental Committee on Intellectual Property and Genetic Resources, Traditional Knowledge and Folklore (IGC) (WIPO/GRTKF/IC/7/INF/5, available www.wipo.int/edocs/mdocs/tk/en/wipo grtkf ic 7/wipo grtkf ic 7 inf 5.pdf) and to the WIPO Ad hoc Intergovernmental Meeting on Genetic Resources and Disclosure Requirement held in June 2005 (WIPO/IP/GR/05/INF/4, available www.wipo.int/edocs/mdocs/tk/en/wipo ip gr 05/wipo ip gr 05 inf 4.doc).

${ }^{42}$ See document PCT/R/WG/8/7, para. 14.

${ }^{43}$ In particular, it has been specified that, according to the new Rule 51 bis $1(\mathrm{~g})(\mathrm{i})$, the obligation arises when the invention makes immediate use of the genetic resource, meaning that it depends on the specific properties of this resources; and the inventor must have had physical access to such resource, intended as "its possession or at least contact which is sufficient enough to identify the properties of the genetic resource relevant for the invention". See document PCT/R/WG/8/7, para 22.

${ }^{44}$ WIPO document PCT/R/WG/7/9, Appendix p. 9.
} 
defines the term "source" as "the entity competent (1) to grant access to genetic resources and traditional knowledge, and/or (2) to participate in the sharing of the benefits arising out of their utilization",46.

Because of the great divergence in the views on such transparency measures, Switzerland has decided to leave the adoption of the requirement optional. ${ }^{47}$ However, thanks to minor adjustments to rules 4.17 and 48.2 , once domestic patent laws implement the requirement the disclosures would become part of the international application as well; hence, they would be published internationally as part of the international patent application $^{48}$.

According to Switzerland, failure to declare the source or wrongful declaration of the source of origin of genetic resources and TK would trigger the application of the sanctions currently allowed for under the PCT and the WIPO's Patent Law Treaty $(\mathrm{PLT})^{49}$. Therefore, in contracting states which have amended national patent laws to implement the disclosure obligation the designated Office shall invite the applicant to

\footnotetext{
${ }^{45}$ Also in this case, it has been later specified that, according to the proposed new Rule 51bis1(g)(ii), the inventor must know that the invention is directly based on such knowledge, in the sense that the inventor "must consciously derive the invention from this knowledge". See document PCT/R/WG/8/7, para. 23.

${ }^{46} \mathrm{WIPO}$ document PCT/R/WG/7/9, supra at footnote 22 , para. 14 . The proposal further distinguishes between primary and secondary sources: namely, on the one side the Contracting Party providing genetic resources and indigenous and local communities and, on the other side, ex situ collections such as gene banks, botanical gardens, databases on genetic resources and traditional knowledge, and scientific literature. The proposal gives a detail explanation on which sources must be disclosed and in which circumstances. Ibidem, para. 15.

${ }^{47}$ The proposal is aimed at amending the PCT Regulations in such a way to explicitly grant national patent legislation the possibility to introduce a (national) norm requiring patent applicants to disclose the source of origin of genetic resources and traditional knowledge.

${ }^{48}$ For an in-depth explanation of the proposal see ibidem, para. 12.

${ }^{49}$ In the view of Swiss delegates, pursuant to the direct reference that the PLT contains, at art. 6.1., to the PCT the proposed amendments to the PCT would also apply to the PLT. See document PCT/R/WG/8/7, paras. 16 and 27.
} 
comply with the requirement within a strict time limit ${ }^{50}$. Moreover, in case of noncompliance, the Office may refuse the application or consider it withdrawn ${ }^{51}$.

Nonetheless if, after the $g$ rant of the patent, it is found out that the patentee has failed to declare the source or it has submitted false information, the proposal establishes that such failure may not be a ground for revocation or invalidation of the patent. ${ }^{52}$

\subsection{A second proposal advanced by southern Developing Countries}

A second proposal has been gradually presented from a group of Developing Countries ${ }^{53}$, namely: Brazil, Cuba, Ecuador, India, Peru, Thailand and Venezuela. Differently from the Swiss proposal just addressed, this second one aims at amending patent provisions contained in TRIPS in such a way to make Developing Countries benefit from WTO dispute settlement procedure ${ }^{54}$. Moreover, this proposal articulates three sub-points and goes far beyond the disclosure of source of origin of genetic resources and traditional knowledge.

The first obligation regards the disclosure of the source and the country of origin of the biological resources and/or traditional knowledge used in an invention within the patent

\footnotetext{
${ }^{50}$ Pursuant to the proposed amended Rule 51bis.3(a) the invitation should be sent at the beginning of the national phase and the time limit set to comply withy the invitation should be no less than two months from the date of invitation. See document PCT/R/WG/8/7, para. 28.

${ }^{51}$ However, if the applicant has submitted the declaration relating to the source of origin and TK within the international application or even later during the international phase, the designated Office must accept it and may not require any further document or evidence relating to the source declared (this, according to the new proposed Rule 51bis.2(d)). See document PCT/R/WG/8/7, para. 28.

${ }^{52}$ Except in the case of fraudulent intention, according to art. 10 PLT. See document PCT/R/WG/8/7, para. 29.

${ }_{53}$ These countries have first submitted a checklist of issues to be dealt with in order to prevent misappropriation of biodiversity and associated traditional knowledge and permit the fulfillment of the other remaining goals of the CBD (basically: ABS). The checklist, which encompasses a set of matters previously discussed at length within the TRIPs Council since 1999, is contained in document IP/C/W/420, 2 March 2004. Each proposed issue has been later articulated in depth during following meetings.

${ }^{54}$ In July 2006, Brazil, China, Colombia, Cuba, India, Pakistan, Peru, Thailand and Tanzania have presented a draft of new art. 29bis, named "Disclosure of Origin of Biological Resources and/or Associated Traditional Knowledge". See document WT/GC/W/564/Rev.2.
} 
application $^{55}$. Like Switzerland, these countries explain that the above disclosure would help solving a variety of problems related to patent law from mere patentability issues to cases regarding disputes on inventorship, entitlement to claim an invention and infringements. However, their proposal is somewhat more effective in that it specifies that the obligation of extra disclosures would be triggered even by a minimal use of the tangible or intangible resources ${ }^{56}$ and envisions a detailed set of legal consequences in case of wrongful or missing disclosure.

In particular, the proposal distinguishes between cases where the wrongful or missing disclosure is discovered before the patent has been granted or examined and, conversely, circumstances where the lack of the requirement is found out at a later stage, when the title of protection has already been issued. In the former case, the patent application should not be processed any further until the applicant complies with the obligation ${ }^{57}$. In the latter case, three different set of consequences are envisioned: a) revocation of the patent, in case the proper disclosure would have turned down the application because of lack of novelty or reasons of ordre public or morality; b) full or partial transfer of the rights to the invention, in case proper disclosure would have shown that the applicant was not the true inventor; c) narrowing the scope of the claims, in case the proper disclosure would have cause them to be curtailed.

\footnotetext{
${ }^{55}$ See document IP/C/W/429/Rev.1., 27 September 2004, presented by Brazil, Cuba, Ecuador, India, Peru, Thailand and Venezuela.

56 " [.... Any use, the disclosure of which is necessary to determine the existence of prior art, inventorship or entitlement to the claimed invention, the scope of the claim and/or is necessary for understanding or carrying out the invention, would be sufficient to trigger the disclosure obligation. In this regard, even where the use was only incidental, it would be sufficient to trigger the obligation if the disclosure of the source and country of origin is relevant for prior art, inventorship or entitlement determinations, the scope of the claim and/or for understanding or carrying out the invention". Ibidem, para. 8.

57 The applicant would have also a time limitation to comply with the disclosure requirement to avoid withdrawal of the patent application. See Ibidem, para. 12.
} 
The second issue regards the disclosure of evidence of PIC under the relevant national regime $^{58}$. Accordingly, patent applicants should bear the burden of providing evidences that national authorities of the country of origin and/or the local or indigenous community have approved the taking of their tangible and/or intangible resources ${ }^{59}$. In case of non-compliance with this extra disclosure requirement a set of legal measures have been proposed, similar to the ones already analyzed above for the disclosure of source of origin ${ }^{60}$.

The third element of the checklist regards the insertion, within the patent application, of documents providing evidence of benefit sharing. Parties explained that such requirement is meant not only for "ensuring that there is benefit-sharing per se but that sharing of benefits is fair and equitable among the parties, taking into account the circumstances of each particular case" ${ }^{\prime 61}$. Such further proof would be provided by showing evidence of an arrangement among the parties for the fair and equitable sharing of any benefit that may arise out of the utilization of the resources ${ }^{62}$.

In case of non-compliance with the latter requirement, the proposal has envisaged legal measures similar to those outlined above in case of erroneous or missing disclosure.

\subsection{The Position of the European Union}

The European Union is at the same time a user and producer of biological resources. Not only has the EU been largely using biological resources for the research and later

\footnotetext{
${ }^{58}$ This second element has been elaborated in document IP/C/W/438, 10 December 2004.

${ }^{59}$ The communal action problem is beyond the scope of this article.

${ }^{60}$ In case of non-compliance before the granting of the patent, the application would not be processed any further until the requested documentation is provided. If a specific time limitation has been set and the inventor does not comply with it, the application would be withdrawn. In case of non-compliance after the patent has been granted, legal measures could include the revocation of the patent or criminal and/or civil sanctions.

${ }^{61}$ See document IP/C/W/442, 4 March 2005, para. 3.

${ }^{62}$ Ibidem, para. 10.
} 
development of vast range of products, but it also is itself the holder of a variety of genetic resources. The core Mediterranean lands are still rich in biodiversity, and many institutions, botanic gardens, etc, own big collections of biological resources. This could surely explain the European proactive involvement in the conservation and protection of such heritage at the international and national level ${ }^{63}$.

Nonetheless, the position of the European Community with regard to the proposed introduction of an extra-disclosure burden for patent applicants has not been straightforward.

On the one side, the EC claims that many provisions already exist within EU laws that are in line with the proposed disclosure of origin requirement. For example, art. 13(1)b of Directive 98/44/CE establishes that where an invention involves the use of biological material not accessible to the public and that cannot be described in such a way to enable the person skilled in the art to practice it, the description of the invention is not deemed sufficient unless, inter alia, the application contains all the relevant information on the characteristics of the biological material deposited ${ }^{64}$. Therefore, the obligation to disclose information regarding the source of origin of certain resources could be already requested, in some cases, by the EC Directive. This assumption seems to finds confirmation in recital 27 of the same Directive stating that "if an invention is based on biological material of plant or animal origin or if it uses such material, the patent

\footnotetext{
${ }^{63}$ Already in 1995 the European Community funded a study on the best possible measures to implement articles 15 and 16 of the CBD. The results of this study have been presented at the third Conference of the Parties within the CBD. The EU has been very active during the negotiation leading to the adoption of the Bonn Guidelines which have been implemented in 2003. See Communication from the Commission to the European Parliament and the Council, The implementation by the EC of the "Bonn Guidelines" on access to genetic resources and benefit-sharing under the Convention on Biological Diversity, Brussels, 23.12.2003, $\operatorname{COM}(2003) \quad 821$ final, available at $\underline{\text { http://europa.eu.int/eur- }}$ lex/lex/LexUriServ/site/en/com/2003/com2003 0821en01.pdf.

${ }^{64}$ Directive 98/44/EC of the European Parliament and of the Council of 6 July 1998 on the legal protection of biotechnological inventions, OJ L 213, 30.7.1998, p. 13-21.
} 
application should, where appropriate, include information on the geographical origin of such material, if known". ${ }^{65}$ Similarly, art. 50 of Regulation n. 2100/94 on Community Plant Variety Rights requires applicants for a community plant variety right to state the geographic origin of the variety ${ }^{66}$.

On the other side, however, the EC recognizes that these provisions do not impose an overall obligation to disclose the country of origin of the biological resources. And indeed the same recital 27 of the aforementioned Directive conditions the disclosure obligation to the circumstance that it does not prejudice somehow the processing of the patent application or the validity of the rights arising from the granted patents. Likewise, the disclosure obligation contained in art. 50 is limited to the variety and does not cover the parent material from which the variety had been developed.

Accordingly, the EC has examined the possibility of inserting the proposed extra disclosure requirement with regard to the source of origin of the biological material. Like the South American countries, The European Community's Member States stand for the implementation of the mandatory requirement at the international and national level ${ }^{67}$; nonetheless, as the Swiss proposal, their request is only limited to the disclosure of the country of origin of the genetic resources and traditional knowledge; and such disclosure would be conditioned both to the circumstance that the invention is directly based on such resources and that the inventors still know about it ${ }^{68}$. Moreover, the EC shares, at

\footnotetext{
${ }^{65}$ Please note that the recitals contained in European Directives do not have a mandatory nature and only serve the purpose of explaining the rationale of the legislation and clarify (or suggest) the meaning of the provisions contained in the legal text. Therefore, European legislators are not compelled to implement them within their national laws.

${ }^{66}$ Council Regulation no. 2100/94 of July $27^{\text {th }} 1994$, on Community plant variety rights, OJ L 227, p. 1.

${ }^{67}$ However, the EC envisions likely modification to the Patent Law Treaty and the Patent Cooperation Treaty, and to regional agreement like the European Patent Convention, but not the TRIPS Agreement.

${ }^{68}$ According to the Swiss proposal, the inventor can also declare that he doesn't know the source of origin of the resources employed in his invention (this would be rule 51bis1, g, iii).
} 
least partially, the American fear about the consequences that lack of compliance with the new requirement could bring about in patent law. Therefore, the EC Members explicitly ask that the disclosure requirement does not amount, de facto or de jure, to an additional formal or substantial patentability criterion and that in case of incorrect or incomplete information, "effective, proportionate and dissuasive sanctions should be envisaged outside the field of patent law"

\section{Why a defensive mechanism by itself is not sufficient}

The proposal of the amendment of international patent laws to insert the above discussed extra-disclosure burdens have met strong opposition by the United States and Japan ${ }^{70}$. The same United States who repeatedly called - and still call - people and countries not respecting American intellectual property laws "pirates" now refuses to give any recognition to indigenous communities' intellectual works, nor is it willing to allow the introduction of any legal mechanism that could grant indigenous tribes some sort of $\operatorname{protection}^{71}$.

\footnotetext{
${ }^{69}$ See the document "Disclosure of origin or source of genetic resources and associated traditional knowledge in patent applications, Proposal of the European Community and its Member States to WIPO, 16 December 2004, para. 8, g, available at www.wipo.int/tk/en/genetic/proposals/european_community.pdf and WTO document IP/C/W383, 17 October 2002, available at http://docsonline.wto.org/DDFDocuments/t/IP/C/W383.doc. The EC has recently restated its position in a document that submitted, on the 17th of May 2005, to the Intergovernmental Committee on Intellectual Property and Genetic Resources, Traditional Knowledge and Folklore, where it has clarified that national patent offices must not be required to make an assessment on the (extra) disclosure information submitted nor must they be obliged to check whether the applicant has gained access to the relevant material in a way that is compatible with the CBD principles of benefit-sharing and prior informed consent. See: $\mathrm{WIPO} / \mathrm{GRTKF} / \mathrm{IC} / 8 / 11$, available www.wipo.int/edocs/mdocs/tk/en/wipo grtkf ic 8/wipo grtkf ic 8 11.pdf, para. 5 .

${ }^{70}$ See documents IP/C/W/434 and IP/C/W/449.

${ }^{71}$ It is well known, indeed, that United States led many Developing Countries to the signing of the TRIPs Agreement through the recourse of $\S 301$ of the Trade Act of 1974. Section 301 is the principal statutory authority under which the United States may impose trade sanctions against foreign countries that maintain acts, policies and practices that violate, or deny U.S. rights or benefits under, trade agreements, or are unjustifiable, unreasonable or discriminatory and burden or restrict U.S. commerce.
} 
According to American delegates, the $\mathrm{CBD}$ does not mention the disclosure requirement, and its introduction would have the perilous effect of destabilizing the patent system by rendering the patent application mechanism excessively burdensome and the validity of the protection uncertain. ${ }^{72}$

It is probably true that a tripartite disclosure requirement, as shaped in the proposal submitted by some Developing Countries, would be too cumbersome for patentees and quite beyond the certification function that patent offices are entitled to perform. Patent officers do not have the skills and the time to evaluate agreements on access and sharing of resources to determine whether indigenous communities are truly granted a fair share of the returns and benefits. However, there is no serious obstacle in amending international patent provisions in order to request just the disclosure of the source of origin of genetic resources and traditional knowledge. This would not be contrary to TRIPS because, although art. 29 TRIPS is silent about the possibility of requesting further disclosures, art. 62.1 TRIPS expressly states that member States can condition the acquisition or maintenance of patents on compliance with reasonable procedures and formalities, provided that they are consistent with the provisions of the Agreement. Since, as we have mentioned earlier, plenty of examples already exist of national patent law requesting extra disclosure burdens, like the American best mode requirement ${ }^{73}$ or the European duty to deposit a sample of the biological material at an accredited institution ${ }^{74}$. The simple request to specify in the patent application the country of origin of the genetic material used in the invention does not amount to an excessive burden; rather, it fits with the reasonableness standard requested by art. 62 TRIPS. Conversely, the threat of patent

\footnotetext{
${ }^{72}$ While this is correct, the requirement has been specifically addressed by the CoP in the Bonn Guidelines. 73 35 U.S.C.A. $\S 112$.

${ }^{74}$ See art. 13 of Directive 98/44 on the legal protection of biotechnological inventions.
} 
invalidation following a lack of disclosure represents an unpleasant but necessary remedy where the envisioning of a pecuniary sanction or a fine would never amount to a credible threat to make patent applicants comply with the requirement.

Having said that, however, it is worth noticing that although the disclosure of origin requirement may be a valuable defensive instrument to protect indigenous people from the issuance of (bad) patents embedding their tangible and intangible property, it is not enough in itself to solve the biopiracy problem and ensure ABS.

CBD provisions wants indigenous people to benefit at large from the results and benefits of the research conducted upon their shoulders, no matter whether they are later embedded in an intellectual property right or kept as trade secrets. Therefore putting all the hopes on the disclosure of patent application -- although it is a significant element -does not solve the issue in that it's not sure that the results of the research will end up in a patent.

\section{Towards a fair and equitable sharing of the benefits associated to biodiversity and traditional knowledge}

As briefly hinted above, the provisions set forth in the CBD calls for two set of faculties to be granted to indigenous communities: namely, the right to be protected against the stealing of their resources and the right to benefit from whatever exploitation of such resources third parties might make. This last faculty is further divided into two: (1) the access to the results of research conducted on biodiversity and TK and (2) the equitable sharing of economic benefits flowing from the exploitation at large of the result of the research. In particular, beyond the general provisions about the sharing in a fair and 
equitable way of the results and benefits set in art. 15(7) CBD, the Convention more explicitly establishes that:

each Contracting Party shall take [... measures [..] with the aim that Contracting Parties, in particular those that are developing countries, which provide genetic resources are provided access to and transfer of technology which makes use of those resources, on mutually agreed terms, including technology protected by patents and other intellectual property rights. ${ }^{75}$

Even more specifically, the Convention underlines the need to grant the countries providing genetic resources effective participation in biotechnological research activities $^{76}$ and priority access on a fair and equitable basis to the results and benefits arising from biotechnologies based upon genetic resources ${ }^{77}$.

The latter faculties depend strongly on the recognition of some form of indigenous community's entitlements towards their tangible and intangible resources. In particular, the right to an economic compensation from the commercial exploitation of the biodiversity finds its justification in the property rights local communities should hold towards their genetic resources ${ }^{78}$. Conversely, the right to access the results of the research conducted on biodiversity and TK lies on the different assumption that Developed Countries borrow scientific knowledge from indigenous people and therefore, with a logic that resembles the open source movement, the latter should not be excluded from benefiting from the resulting applications of their knowledge. However, the intangible character of TK makes the recognition of right over traditional knowledge

\footnotetext{
${ }^{75}$ Art. 16(3) CBD (emphasis added)

${ }^{76}$ Art. 19(1) CBD.

${ }^{77}$ Art. 19(2) CBD.

${ }^{78}$ Such rights, further affirmed in the CBD, should be easily recognizable by Developed Countries because of the tangible character of the resources.
} 
more difficult. As it has been pointed out, indigenous people have their own system and traditions for the use and employment of their knowledge. Unfortunately, foreign companies filter traditional medical knowledge through the lenses of industrialized intellectual property systems, and get the misconceived perception that $\mathrm{TK}$ is free for everyone to take and make profits out of it.

\section{Crafting some sort of entitlement for traditional knowledge owners}

Two proposals have been presented which are worth analysing. The first comes from academia and it is the fruit of legal and economic expertise joined together. The second proposal was prepared by the WIPO Secretariat and presented at the April 2006 session within the Intergovernmental Committee on Intellectual Property and Genetic Resources, Traditional Knowledge and Folklore, in Geneva.

\subsection{Liability rules for indigenous communities? Pros and cons}

For the reasons outlined above, supporters of strong IP protection tend to underline traditional knowledge incompatibilities with current IP regimes. Conversely, "publicinterest advocates" fear the introduction of any form of proprietary rights in traditional knowledge because of the likely adverse effect on the public domain ${ }^{79}$.

An interesting intermediate proposition has been recently put forward by Professor Reichman and Professor Lewis about a tentative attempt to regulate traditional knowledge under a compensatory liability regime (CLR). ${ }^{80}$ According to their model,

\footnotetext{
${ }^{79}$ T. Cottier \& M. Panizzon, Legal perspectives on traditional knowledge: The case for intellectual property protection, in INTERNATIONAL PUBLIC GOODS AND TRANSFER OF TECHNOLOGY UNDER A Globalized Intellectual Property Regime, edited by K. Maskus \& J.R. Reichman, Cambridge, 2005, p. 577 and ff.

${ }_{80}$ J.H. Reichman \& T. Lewis, Using liability rules to stimulate local innovation in developing countries: Application to traditional knowledge, in INTERNATIONAL PUBLIC GOODS AND TRANSFER OF TECHNOLOGY
} 
elaborated by Professor Reichman in two previous articles ${ }^{81}$, traditional knowledge owners would be provided, for a limited time, the following rights: a) the right to prevent second comers from entering TK owners' product market with a slavish imitation of their product; b) the right to a reasonable compensation from follow-on innovators who make improvement upon their scientific knowledge; and c) the right to make use of second comers' own technical improvements for purposes of further improving their initial products $^{82}$.

The core of the proposal closely resembles what I have suggested elsewhere for computer programs $^{83}$. The authors explain that Developing Countries could greatly benefit from an entitlement system based on liability rules rather than property rights for at least two reasons. On the one side, Developing Countries' industries are often characterized by a set of small and medium-sized enterprises rather than big and powerful companies. This means that titles of protection like patents, for example, which are costly both to obtain and to litigate, may not be the first best option to spur technological progress. It is well known that Developing Countries, like India or Korea for example, have largely benefited from imitation rather than creation ${ }^{84}$. On the other side, the authors, agreeing with the Developed Countries' perspectives, stress the nature of traditional knowledge as

Under a Globalized Intellectual Property Regime, edited by K. Maskus \& J.R. Reichman, Cambridge, 2005, p. 337 and ff.

${ }^{81}$ J.H. Reichman, Legal Hybrids between the Patent and Copyright Paradigms, 94 COLUMBIA L.ReV. 2432 (1994); and: Of Green Tulips and Legal Kudzu: Repackaging Rights in Subpatentable Innovation, 53 VAND. L. REV. 1743 (2000).

${ }^{82}$ J.H. Reichman \& T. Lewis, Using liability rules to stimulate local innovation in developing countries: Application to traditional knowledge p. 349 and ff.

${ }^{83}$ My proposal draws on the scheme laid out by art. 31(l) TRIPS establishing a cross-licensing mechanism for high-profile innovations whereby only truly innovative second comers are entitled a license on the first blocking patent and, in turn, are compelled to grant access to first inventors to their dependent innovation. See G. Ghidini \& E. Arezzo, Patent and copyright paradigms vis-à-vis derivative innovation: the case of computer programs, in IIC, n.2, 2005, p.159.

${ }^{84}$ Funnily enough, Developed Countries referred to this as free-riding but are reluctant to see any kind of similar phenomenon in the biosquatting of genetic resources and TK. 
sub-patentable subject matter; they define traditional knowledge as technical know-how that does not meet both copyright and patent eligibility requirements and therefore - in IP jargon -- it would be otherwise left out in the public domain. ${ }^{85}$ Conversely, a CLR system would place genetic resources and $\mathrm{TK}$ in a semi-commons pool where scientific information can be easily shared because access is not forbidden ${ }^{86}$. Conversely, freeriding is.

This proposal is one of the most interesting suggestions advanced so far. Such a system indeed, on the one side, would entitle indigenous people to get compensation from third parties' exploitation of their tangible and intangible resources; but on the other hand, it would not grant them the right to block access to third parties.

This system would surely spur innovation and enrich Developing Countries; nonetheless such system carries some significant limitations.

From a normative point of view, CLR seems to conflict with the very aims of the CBD which expressly refers to the Developing Countries' sovereignty over biodiversity related resources as a fundamental right and, negotiating tools to properly deal with Developed Countries' firms. From a practical point of view, it is not clear how such a regime could coexist with traditional IPR systems either inside or outside Developing Countries' territories.

Developing Countries (at least most of them) have adhered to the TRIPS Agreement and sooner or later they will all be compelled to shift from their local IP-like property system

\footnotetext{
${ }^{85}$ Especially, authors stress that traditional knowledge would not pass the non-obviousness hurdle.

${ }^{86}$ See on this point also J.H. Reichman, Saving the Patent System from Itself, Informal Remarks Concerning the Systemic Problems Afflicting Developed Intellectual Property Regimes (2003) in Perspectives on Properties of the Human Genome Project, edited by F.S. Kieff, Elsevier Academic Press, Oxford, (2003), 289.
} 
towards internationalized IP standards ${ }^{87}$. This means that a CLR system, adopted in a developing country, would have to coexist with traditional IPRs, especially with patent law. Arguably, this should not be considered a problem because patent law is supposed to have a higher standard of protection, filtering only truly non-obvious innovations. However, it is also well known that this trend, at least in the United States, has been sensibly lowered. ${ }^{88}$ Therefore it is not crystal clear how the two regimes could dissect separate spheres of application. Moreover, even assuming that such a separation could actually be feasible, it is not clear what would happen if, let's say, an inventor would pay compensation for the taking of TK off the semi-commons pool and then, thanks to a breakthrough discovery, would succeed in patenting his invention.

Besides these concerns, the coexistence of a CLR system in foreign countries with foreign IP systems is even more worrisome.

The authors clearly state that, lacking any treaty obligation, "members would not be entitled to demand for their citizens that foreign countries reciprocally provide similar CLR protection abroad" 89 . Nonetheless, they argue that this circumstance is not as troubling as it may initially seem because both the Paris Convention and TRIPS would allow Developing Countries' citizens to claim patent and utility model rights abroad, in

\footnotetext{
${ }^{87}$ At the end of November 2005, the WTO's Council for TRIPS decided to extend least Developed Countries' transition period for the implementation of IP provisions (which was supposed to expire on January $1^{\text {st }} 2006$ ) by seven and a half years. See Decision of the Council for TRIPS of 29 November 2005, (Press/424), EXTENSION OF THE TRANSITION PERIOD UNDER ARTICLE 66.1 FOR LEASTDEVELOPED COUNTRY MEMBERS, available at http://www.wto.org/english/news_e/pres05_e/pr424_e.htm.

${ }^{88}$ This trend has been punctually described by J.H. Reichman, Saving the Patent Law from Itself: Informal Remarks Concerning the Systemic Problems Afflicting Developed Intellectual Property Regimes, in Perspectives on Properties of THE Human GenOME Project, edited by F.S. Kieff, Elsevier Academic Press, San Diego CA, 2003, p 294.

${ }^{89}$ J.H. Reichman \& T. Lewis, Using liability rules to stimulate local innovation in developing countries: Application to traditional knowledge, p. 364.
} 
countries that do not have a similar CLR system. ${ }^{90}$ This is certainly true, but so far we have being looking at the issue from a different angle.

As outlined earlier on in this paper, the problem at issue here does not concern the fostering of Developing Countries' industries through the exploitation of traditional knowledge and their imports abroad. Indeed, it is very well clear that indigenous people (if their countries are TRIPS signatories) are entitled to ask for patents or utility model protection abroad once their innovations fulfil the requirements set forth by foreign legislations.

On the contrary, the concern examined here is biopiracy, i.e. about how to impede foreign third parties from collecting Developing Countries' biological resources and traditional knowledge, bringing it back to their own countries, obtaining patents and/or other property rights and then either commercializing the results only in their territories or asking for IP protection in Developing Countries in such a way to impede them to further use their own resources. Therefore, the attention is especially focused on the implementation or amendment of supra national provisions that can grant local communities protection against act of misappropriation that usually take place abroad ${ }^{91}$. Although the CLR comes close to the sort of entitlement I would like to shape for traditional knowledge, this regime does not seem suited to solve the issue of biopiracy.

\footnotetext{
${ }^{90}$ At the moment, all.

${ }^{91}$ My point of view is shared by Cottier and Panizzon who explain that: "Protection of TK is only effective if it binds industrialized and Developing Countries alike. This is only possible with a global-scale protection”. See T. Cottier \& M. Panizzon, supra, at 581.
} 


\subsection{The document drafted by the WIPO Intergovernmental Committee on Intellectual Property and Genetic Resources, Traditional Knowledge and Folklore}

Since 2001, the WIPO Intergovernmental Committee on Intellectual Property and Genetic Resources, Traditional Knowledge and Folklore (hereinafter "the Committee" or "IGC") has periodically met to discuss a draft of provisions expressly meant to enhance protection of TK and traditional culture against its misappropriation ${ }^{92}$ and misuse ${ }^{93}$.

The document comprehends three different portions. Its first part contains so called policy objectives and it is intended to provide a consistent policy framework for protection $^{94}$. The second part contains general guiding principles aimed at ensuring consistency, balance and effectiveness of substantive principles contained in part three ${ }^{95}$. The last part, indeed, comprehends a set of substantive provisions which define the very concept of TK, draw the scope, duration, and formalities of protection, establish who should be the entitled owner of such protection.

\footnotetext{
${ }^{92}$ As is well known TRIPS adopted, via art.2.1, the unfair competition provisions contained in art.10bis of the Paris Convention for the Protection of Industrial Property. Although the list contained in art.10bis(3) is not exhaustive and art.10bis(2) explains that "[A]ny act of competition contrary to honest practices in industrial or commercial matters constitutes an act of unfair competition", the lack of express mentioning of misappropriation has led to the different shaping of unfair competition in different countries. For example, in the United States unfair competition provisions are contained in half provision of the Lanham Trademark Act (namely: section 1125(a)) and only ban (in broad terms) conducts aimed at ingenerating confusion relating to the origin of the goods and misleading advertisings. A misappropriation doctrine has been developed but apparently it regards very fact-specific issues. See INS v. AP, 248 U.S. 215 (1918).

${ }^{93} \mathrm{See}$ document WIPO/GRTFK/IC/9/5 last discussed by the Intergovernmental Committee on Intellectual Property and Genetic Resources, Traditional Knowledge and Folklore, during the ninth session in April 2006. The document is available at http://www.wipo.int/edocs/mdocs/tk/en/wipo_grtkf_ic_9/wipo_grtkf ic_9 5.doc.

${ }^{94}$ Among the most relevant policy objectives there are: the recognition of the holistic nature of TK and the acknowledgment that TK systems are frameworks of "ongoing innovation and distinctive intellectual and creative life"; the importance of meeting the actual needs of TK holders as well as the conservation and preservation of TK itself. See WIPO/GRTFK/IC/9/5, annex, p. 3.

${ }^{95}$ Among the most relevant guiding principles there are: the principle of recognition of rights; the principle of effectiveness and accessibility of protection; the principle of equity and benefit-sharing; the principle of consistency with existing legal systems governing access to associated genetic resources. See WIPO/GRTFK/IC/9/5, Annex, p. 8.
} 
While the stakeholders taking part to the meetings promoted by the Committee have largely agreed on the policy objectives and guiding principles informing protection, it seems that there is still some disagreement as to the specific form of protection to be implemented (i.e. part three of the document) ${ }^{96}$.

As to the substantive portion of the document, the Committee has drafted an ample definition of traditional knowledge as comprehending the know-how, skills, innovations, practices and knowledge that form part of the lifestyle of indigenous and local communities; and it stresses the variety of fields that TK can cover from agriculture to environment and medicine. $^{97}$

The intergenerational character of TK and, in general, its collective nature is also stressed insofar as it represents the requirement to filter out which traditional knowledge deserves protection and who should be the holder ${ }^{98}$.

Art. 5 establishes that protection may benefit communities themselves that hold collectively the knowledge as well as recognized individuals within these communities and people. The proposal further envisages no formalities for the recognition of the protection which should last as long as the requirements listed in article 4 stay fulfilled ${ }^{99}$. As the CLR regime outlined above, the Committee's proposal does not imply the creation of a new intellectual property right; rather, like Europe's perspective on companies' goodwill, it recognizes the value of traditional knowledge as shared scientific know-how,

\footnotetext{
${ }^{96}$ In this sense see document WIPO/GRTFK/IC/8/15.

${ }^{97}$ See Document WIPO/GRTFK/IC/9/5, supra, III. Substantive Provisions, art. 3(2).

${ }^{98}$ Art. 4 holds that protection should be extended, at least, to TK which is: "(i) generated, preserved and transmitted in a traditional and intergenerational context; (ii) distinctively associated with a traditional or indigenous community or people which preserves and transmits it between generations; and (iii) integral to the cultural identity of an indigenous or traditional community or people which is recognized as holding the knowledge through a form of custodianship, guardianship, collective ownership or cultural responsibility. This relationship may be expressed formally or informally by customary or traditional practices, protocols or laws.

${ }^{99}$ Ibidem, article 11 and 9.
} 
innovations and practices, and affords to the legitimate owners the right to stand against the misappropriation and misuse of their intangible knowledge.

The provision drawing protection against misappropriation is divided into three prongs. A first proposition generally states that TK shall be protected against misappropriation. A second prong describes the nature of misappropriation in general as any acquisition, appropriation or utilization of TK by unfair or illicit means. Further, the provision adds that misappropriation may also include "deriving commercial benefit from the acquisition, appropriation or utilization of traditional knowledge when the person using that knowledge knows, or is negligent in failing to know, that it was acquired or appropriated by unfair means; and other commercial activities contrary to honest practices that gain inequitable benefit from traditional knowledge" ${ }^{\prime 100}$.

The provision does not give a closed definition of TK; rather, it eloquently recalls general unfair competition principles, well rooted in civil law countries. The link to article 10bis, further contained at art. 1, paragraph 4, is important in that it leaves countries free to determine what may constitute misappropriation according to their own legal principles and traditions. ${ }^{101}$

The article further lists, in paragraph 3, a group of behaviors that should be specially prevented $^{102}$. However, the incipit "in particular" at the very beginning of prong three leaves it open to national legislators to envisions additional forms of misappropriation and misuse of TK.

\footnotetext{
${ }^{100}$ Ibidem, art.1(2).

${ }^{101} \mathrm{See}$ WIPO/GRTFK/IC/9/5, Commentary on Art. 1.

${ }^{102}$ Included among these there are: (i) the illicit acquisition of TK, including by theft, bribery, deception, breach of contract, etc; (ii) breach of the principle of prior informed consent for access to TK (when it is required under national or regional measures); (iii) breach of defensive protection measures of TK; (iv) commercial or industrial uses which misappropriate the value of TK where it is reasonable to expect the holders of TK to share the benefits from this use; and (v) willful morally offensive uses of TK which is of particular moral or spiritual value to the TK holder.
} 


\section{A colonialist model of intellectual property?}

Why is it so difficult to envisage a form of proprietary right for local communities towards their intangible works? Many answers can be given to this question.

First of all, the type of intellectual works protected and rewarded by modern intellectual property regimes appears quite different from the creative model embraced by local indigenous communities. Both patent and copyright paradigms respond to the needs of a market economy; they serve the purpose of monetizing intellectual creations by making their commercial exploitation possible. These systems therefore, although not on purpose, sets rules with which indigenous people's creations find impossible to comply.

Secondly, it has been observed that industrialized intellectual property systems reward only the creative efforts and transformation of raw inputs, giving no value to the raw materials in themselves which traditionally have represented Developing Countries' competitive advantage ${ }^{103}$. This, in theory, should not be criticized. IPRs came about to protect intangible works therefore it is no surprise that within IP paradigms no reward is envisioned towards raw materials. But this is not because raw materials have no value. It's simply because raw materials, being tangible, should be normally subject to traditional property rights.

Nevertheless, the case of biodiversity is different from traditional property. On the one hand, Developing Countries lack measures to efficaciously prevent the unauthorized taking of their resources. On the other hand, the extremely tight link between biodiversity and related traditional knowledge makes the status of the former very peculiar and close to that of intangible property itself ${ }^{104}$.

\footnotetext{
103 J. Boyle, Shamans, Software AND SpleEns, p. 126.

${ }^{104}$ See supra para. 1.2 and 1.3.
} 


\subsection{Alleged barriers to create an entitlement to intangible TK associated to biological resources}

As many have reasonably observed, western intellectual property systems are specifically framed to reward and protect the innovator of the industrial revolution and end up disfavoring Developing Countries' ways of contributing to science and culture ${ }^{105}$. According to Professor Boyle, the first sign of this imbalance has been found in the concept of authorship (or, alternatively, "inventorship") which "stands as a gate through which one must pass in order to acquire intellectual property rights"106. A significant passage from the Bellagio Declaration expresses clearly the concept:

Contemporary intellectual property law is constructed around the notion of the author, the individual, solitary and original creator [...]. Those who do not fit this model - custodians of tribal culture and medical knowledge, collectives practicing traditional artistic and musical forms, or peasant cultivators of valuable seed varieties, for example -- are denied intellectual property protection. ${ }^{107}$

Allegedly, developing and Developed Countries differ in that the collaborative creative process of the former (opposed to the individualistic one typical of the latter) makes it somehow hard to identify and reward, through the granting of an exclusive right, the true

\footnotetext{
${ }^{105}$ As professor Blakeney has vividly pointed out, traditional knowledge (and folklore) is at odds with all common intellectual property principles: "Authorship is replaced by a concept of interpretation through initiation. Ownership yields to a concept of custodianship of dreamings, or legend. Alienation is contradicted by the concept of immutable communal property. Exploitation is subject to cultural restrains and taboos". M. Blakeney, The protection of traditional knowledge under intellectual property law, E.I.P.R. 2000, 22(6), 251.

${ }^{106}$ J. Boyle, SHAMANS, SofTwARE AND SPLEENS, p. 125.

${ }^{107}$ The Bellagio Declaration (whose text can be found in Boyle, SHAmANS, SoFTwARE AND SPLEENS, p.192 and ff.) has been signed in 1992 by lawyers, anthropologists, environmentalists, computer experts, literary critics and activists to address the growing worldwide concerns given by the expansionist trend of intellectual property laws. Specifically, the Declaration was meant to condemn the effect that intellectual property laws have on Developing Countries.
} 
author/inventor. Furthermore, this very same collaborative process has a highly cumulative character and it slowly advances through generations. Usually, all members of the community contribute in different amounts and in different moments to the enlargement of the knowledge so that no significant breakthrough can be identified at a certain time, but rather only a continuous flow of small bits of innovations. This difficulty is somewhat increased by the ephemeral - rectius: unfixed - character of the innovations that are orally passed from one generation to the other ${ }^{108}$, so that it is impossible to discern, within the group, who discovered what in a precise moment ${ }^{109}$.

It has been further argued that traditional knowledge holders cannot protect their knowledge or its related practical application through current patent laws because the fruit of indigenous people's intellectual labor would not meet the requirements of novelty and non-obviousness ${ }^{110}$. Moreover, it has been pointed out that, from a European perspective, the type of innovations brought about by indigenous people could never receive patent protection because they would amount to mere discoveries ${ }^{111}$. While this obstacle would probably be easier to overcome through the American "product of nature"/"human-made inventions" dichotomy ${ }^{112}$, this is not the point at issue here. All the

\footnotetext{
${ }^{108}$ Indeed, recall that for both patent and copyright paradigms the fixation of the subject matter represents, for different reasons, a precondition for the granting and/or recognizing of protection.

109 This has been alleged to be a further obstacle because even if patent law envisages some form of collective inventorship it strictly requires that all claimed inventors have contributed to the innovation and that it is possible to discern the contribution of each of them. See G. Van Overwalle, Protecting and sharing biodiversity and traditional knowledge: Holder and user tools, supra footnote 10, at 594.

${ }^{110}$ J.H. Reichman \& T. Lewis, Using liability rules to stimulate local innovation in developing countries: Application to traditional knowledge; J. Koopman, Bumps and Bends in the Road to Intellectual Property for Traditional Knowledge, supra note 7, at 261. G. Van Overwalle, Protecting and sharing biodiversity and traditional knowledge: Holder and user tools, supra note 10, at 593.

${ }^{111}$ J. Koopman, Bumps and Bends in the Road to Intellectual Property for Traditional Knowledge, supra note 7 , at 261 .

${ }^{112}$ It is commonly accepted in European patent laws the principle that discoveries cannot be patented because they do not amount per se to inventions. This principle is also stated in the European Patent Convention, (Convention on the Grant of European Patents, of October $5^{\text {th }} 1973$, hereinafter EPC) at art. 52.2(a). Differently, American patent law does not ban discoveries from patentable subject matters $(\S 101$
} 
objections rose against TK-owners' capability to invoke patent protection lie on the misconceived assumption that they indeed want to obtain such protection, which we don't know considering that indigenous people have their own rules and mores $^{113}$.

Conversely, these objections play in favor of foreign researchers who feel entitled to take whatever is not subject to their intellectual property scheme and is therefore free. Foreign enterprises look at traditional knowledge through the lenses of industrialized intellectual property systems and because they do not see any patent or patent-like rights, they consider TK as forming part of the public domain ${ }^{114}$.

This assumption is further corroborated by the fact that often western ethnobotanists and biologists publish - with no authorization -- the results of their studies based on investigation of indigenous communities' scientific knowledge. Obviously, such knowledge, unlawfully disseminated, is then deemed to be in the public domain. This assumption is also misconstrued and biased towards the interests of Developed Countries' firms ${ }^{115}$.

U.S. 35) but with regard to biotechnological invention the Supreme Court drew a distinction between naturally occurring things, hence not patentable, and "product of human ingenuity having a distinct name, character and use". See Diamond v. Chakrabarty, 447 U.S. 303, 100 S.Ct. 2204, (1980).

${ }^{113}$ Besides, as shown by Professor McManis the Aguaruna people, within the mentioned ICBG-Peru project have been granted the possibility to file for patents in the U.S.A. and have successfully obtained several titles of protection as exclusive inventors; in other cases they have been recognized as contributors within the patent application. C. McManis, Intellectual Property, Genetic Resources and Traditional Knowledge Protection: Thinking Globally, Acting Locally, supra note 11, at 574.

${ }^{114}$ In fact, quite often notwithstanding the circumstance that their countries have implemented intellectual property regimes, local communities respond to their oral traditions and rules and do not ask for patent protection.

${ }^{115}$ Indeed, such knowledge is often subjected to local IP-like property system and an unauthorized publication should not be considered by western countries as putting the innovation in the public domain; rather, as it happens with the publication of patent applications, such disclosure should have the effect of preserving the knowledge contained therein but clarifying its belonging to the state of the art. 


\subsection{Protectionist measures}

In the recent American case In re Cruciferous Sprout Litigation the United States Court of Appeals for the Federal Circuit (CAFC) affirmed the district court decision invalidating three patents for anticipation. ${ }^{116}$ The patents regarded methods of preparing food products (specifically: sprouts) containing certain enzymes (Phase 2 enzymes) with a chemoprotective effect against cancer. The Court found that the inventions were not novel because the alleged properties claimed by the applicant were inherent to the sprouts, no matter whether persons skilled in the art were or were not aware of it. ${ }^{117}$ The principle underlying the decision was that it was inappropriate to grant a patent whose alleged benefits where already acquired by society.

This rigor unfortunately does not apply if the beneficial properties belong to a plant growing on a Developing country's soil. Indeed, U.S. patent system establishes that anticipation can be caused only by what was "known or used by others in this country [U.S.A.] or patented or described in a printed publication in this or a foreign country, before the invention thereof". 118 This means that no matter how well-known the indigenous scientific knowledge may have been abroad, no protection whatsoever can be granted if the foreign information is not contained in a formal publication.

This over-protectionist attitude can no longer be justified in today's environment where technology not only allows people to travel extensively but also allows knowledge to travel even faster, with no need to be embedded in a formal scientific publication. This does not mean that each piece of knowledge somewhere in the globe must necessarily

\footnotetext{
${ }^{116}$ In re Cruciferous Sprout Litigation, 301 F.3d 1343, cert. denied, 538 U.S. 907 (2003).

117 This is the so called "inherency doctrine" which is part of the novelty inquiry. See M. Lemley \& D. Burk, Inherency, 47 WiLliam AND MARY L. REV. 371 (2005).

11835 U.S.C. $\$ 102(a)$.
} 
constitute prior art and, consequently, be capable of invalidating a patent; simply, traditional knowledge should be subject to general anticipation rules. ${ }^{119}$ Conversely, if such knowledge may not be extensively spread to society at large but it was nevertheless very well known by the experts of the field, there is no reason why it should not be deemed part of the state of the art and be taken into account when evaluating the obviousness of the invention. ${ }^{120}$

A different approach has been implemented in European Countries where the state of the art comprises "everything made available to the public by means of a written or oral description, by use, or in any other way, before the date of filing of the [...] patent application" 121 .

Recently, India has applauded the Board of Appeal of the European Patent Office's decision to turn down a patent application based on the Azadirachta Indica's chemical properties (i.e. a method for controlling fungi on plants by the aid of hydrophobic

119 According to well-settled American case law, anticipation occurs when the prior art has been sufficiently disclosed and circulated among the public (see Gayler v. Wilder, 51 U.S. 477 (1850)); however, depending on the circumstances of the case, even "the prior knowledge and use by a single person is sufficient" (35 U.S.C. $§ 102$ (2006); Coffin v. Ogden, 85 U.S. 120 (1873)). The anticipation inquiry does not allow combination of prior art. To have anticipation, one single prior art must anticipate the whole invention. 35 U.S.C. 102 (2006); Among the several amendments recently submitted and discussed to amend American patent law, a proposal has been presented to broaden the prior art analysis to all pieces of knowledge "otherwise known before the effective filing date of the application". A draft of the proposed patent statute can be found at http://patentlaw.typepad.com/patent/DraftPatentStatuteDDC.pdf.

${ }_{120} 35$ U.S.C. 103 (2006).

${ }^{121}$ The text reported above is art. 54 of the EPC. Although such article does not expressly mention foreign publication and prior uses, such is clear from EPO case law. Moreover, a further confirmation of the different European attitude can be found in the text of the U.K. and Italian patent laws which expressly include foreign prior arts. (Art. 2(2) U.K. Patent Act 1977 reads: "The state of the art in the case of an invention shall be taken to comprise all matter (whether a product, a process, information about either, or anything else) which has at any time before the priority date of that invention been made available to the public (whether in the United Kingdom or elsewhere) by written or oral description, by use or in any other way". Emphasis supplied. Similarly, Italian Patent Law, now codified in the new Italian Code of Industrial Property establishes that: "Lo stato della tecnica è costituito da tutto ciò che è stato reso accessibile al pubblico nel territorio dello Stato o all'estero prima della data del deposito della domanda di brevetto, mediante una descrizione scritta od orale, una utilizzazione o un qualsiasi altro mezzo" (art.46(2)). This translates in English approximately to: "the state of the art comprehends everything made accessible to the public within the territory of the State or in foreign countries, before the patent application has been filed and deposited, in written form or through oral transmission, use or in whatever other means (that implies its accessibility)". 
extracted neem oil). ${ }^{122}$ The Opposition Division of the EPO, pursuant to art. 102(1) EPC, found that public prior use had been proven on the basis of Mr. A.D. Phadke's testimony ${ }^{123}$ and related affidavit, and that the patent therefore had been anticipated. ${ }^{124}$ The Opposition Division held that the patent lacked inventive step also ${ }^{125}$. Although the Board of Appeal did not further investigate on whether Mr. Phadke's testimony could be part of the prior art, and it rejected the Opposition Division finding about novelty, it nonetheless confirmed that the invention lacked inventiveness ${ }^{126}$. Please note that such result would not be possible under US patent law where prior arts cannot be combined for non-obviousness purposes lacking an express motivation ${ }^{127}$.

122 Case Thermo Trilogy Corporation et al. v. Aelvoet Magda. MEP, the Green Group in the European Parliament et al., Decision T 0416/01, $8^{\text {th }}$ March 2005.

${ }^{123} \mathrm{Mr}$. Phadke witnessed that he had himself carried out some of the tests on the fungicidal effect of the neem tree with two farmers in summer 1985 and 1986.

${ }^{124}$ Case Thermo Trilogy Corporation et al. v. Aelvoet Magda. MEP, the Green Group in the European Parliament et al., Decision T 0416/01, $8^{\text {th }}$ March 2005.

${ }^{125}$ After having defined the state of the art, the Opposition Division defined the technical problem to be solved as the finding of alternative methods for controlling fungi or protecting plants. Given the fact that the neem tree's properties in that sense were already known, the EPO found the invention obvious because the skilled person would have easily turned to lower concentration of neem oil extract as an obvious cheap alternative to the known formulations. Ibidem, para. IV.

${ }^{126}$ Please note that the Board of Appeal did not rule out the possibility for oral prior art to form the "state of the art" for novelty and inventiveness analysis; rather, in the case at issue, the Board preferred not to inquire further because the appellant argued that such prior use was not enough documented. Since the affidavit confirmed what was contained in the oral testimony, the Board decided not to investigate the issue further

127 According to a well settled case law of the CAFC [see: In re Kotzab, 217 F.3d 1365, 1370 C.A. Fed. 2000; In re Dance, 160 F.3d 1339, 1343, 48 USPQ2d 1635, 1637 (Fed.Cir.1998); In re Gordon, 733 F.2d 900, 902, 221 USPQ 1125, 1127 (Fed.Cir.1984)] to establish obviousness based on a combination of the elements disclosed in the prior art, there must be some motivation, suggestion or teaching of the desirability of making the specific combination that was made by the applicant (35 U.S.C. $\S 103(a)$ ).

Nonetheless, the same CAFC recently seems to have endorsed a more relaxed approach towards obviousness standards (see Ruiz v. A.B. Chance Co., 357 F.3d 1270, 1276-1277, 69 USPQ2d 1686, 16901691 (Fed. Cir. 2004). where the court held that motivation to combine the teaching in the prior art may come from the nature of a problem to be solved, even when there is not an express written teaching suggesting combination); and recently there have been hearings before the U.S. Supreme Court for a petition of certiorari on a patent case which could severely change the approach towards non-obviousness analysis in patent cases, especially with regard to the possibility to combine prior arts. See KSR v. Teleflex, (126 S.Ct. 327, U.S. 2005). 


\section{Downsides of the colonialist approach and possible ways out}

Art.16(5) of the CBD provides that " $[\mathrm{t}]$ he Contracting Parties, recognizing that patents and other intellectual property rights may have an influence on the implementation of this Convention, shall cooperate in this regard subject to national legislation and international law in order to ensure that such rights are supportive of and do not run counter to its objectives" (emphasis added). However, from what we have seen in the previous paragraphs, the way modern intellectual property law is shaped seems to put TK-holders at a disadvantage.

Nonetheless, upon closer look, the obstacles that we have examined earlier about the concept of authorship and the impossibility of attributing the innovation to its actual inventor, or the lack of written form and so on do not amount to such a hurdle to overcome. For example, the concept of authorship in copyright law and the related concept of originality have, at least in American copyright law, a constitutional value and basis. ${ }^{128}$ The bond between the author and his work is crucial in that the rewarding mechanism which spurs the creation of intellectual works lie on the assumption that compensation goes to the original author. This ideal figure, however, has been stretched at will to accommodate companies' needs so that, nowadays, corporations can be attributed direct authorships of software programs (probably created by a group of programmers deprived even of the paternity of the work), of motion pictures, musical composition and so on via the so-called Work for Hire doctrine. ${ }^{129}$ If corporations can be

\footnotetext{
${ }^{128}$ The so called Copyright Clause (US Constitution, article 1, section 8) reads: "Congress shall have the power $[\ldots]$ to promote the Progress of Science and useful Arts, by securing for limited Times to Authors and Inventors the exclusive Right to their respective Writing and Discoveries".

${ }^{129} 17$ U.S.C. $\S 101$ and $201(b)$.
} 
attributed authorship for works created by others, why shouldn't indigenous communities be held owners of the TK collectively produced by their members? ${ }^{130}$

At first glance, the hurdles relating to patentability requirements might seem more complex, but even in this case the obstacles are not insurmountable ${ }^{131}$. As explained earlier, however, the purpose of this work is not to analyze whether small scale innovations brought about by indigenous people can or cannot satisfy patent eligibility standards. Rather, this study starts from the assumption that these indigenous communities have their own legal systems which regulate the sharing of biodiversity and traditional knowledge within each community. What they do need is a legal instrument that enables them to prevent others to take with no authorization their resources and make profits out of them.

Within this framework, patent protection is a possible option to protect such knowledge but it would not always be a feasible one. This is because, on the one side, patent protection is very expensive to obtain; hence, it seems very unlikely that indigenous community would find the economic resources to hire lawyers to codify their knowledge into patent applications and then file for patent protection locally and abroad. On the other side, as mentioned earlier, the mixture of traditional knowledge and biodiversity can well give rise to innovations which are already suitable for patent protection $^{132}$, but it can also just point out promising research paths which require more in-depth study and experimentation to get to a valuable economic result.

\footnotetext{
${ }^{130}$ Always at this regard it is interesting to notice that copyright law further envisions forms of collective ownership when the creative work is the fruit of a collective effort. See 17 U.S.C. 101 and 201 (c).

131 Indeed, if indigenous community would decide to "sell" their collective knowledge in capital economies, nothing could prevent them from recurring to patent protection, provided that their country has adopted a patent system and that their innovations, like any other, conform to patentability requirements.

${ }^{132}$ For example, shamanic knowledge could discover that the leaves of a certain plant, when boiled for a certain time and then dried to the sun acquire healing properties to cure a certain disease. Such discovery would be in itself an invention.
} 


\subsection{The adoption of a misappropriation regime}

For the reasons explored above, an entitlement shaped in the form of a misappropriation right like the one presented by the WIPO IGCmight represent a very promising opportunity; although some minor adjustments are necessary.

\subsubsection{Misappropriation in the form of a negative entitlement and its advantages over an exclusive right}

As hinted above, the recognition of some form of entitlement on traditional knowledge owners is fundamental for their participation in the resulting applications of their resources under a twofold perspective: on the one side, it is crucial to justify their entitlement to economic compensation from whatever employment of their knowledge, be it patented or not ${ }^{133}$; on the other side, it is essential for them in order to compel users to bring dependent innovations back to the common research pools at their own disposal; on the other side.

However, the creation of a strong property right on TK would run counter the interests of Developed Countries which would not want TK owners to be vested with the exclusive right to foreclose access to scientific indigenous knowledge. As long as this power may be capable of relenting scientific innovation at large, the overall society might be worse off.

Conversely, it is interesting to notice that even indigenous people have expressed the desire that their intangible knowledge be not embedded into strong exclusive property rights. This is because they probably fear that such a regime, if implemented even locally,

${ }^{133}$ G. Ghidini, Equitable sharing of Benefits from Biodiversity-Based Innovation: Some Reflections under the Shadow of a Neem Tree, in InTERnational Public Goods And Transfer Of TechnOlOGy UndER A Globalized Intellectual Property Regime, edited by J.H. Reichman and K. Maskus, Cambridge MA, 2005. 
might prevent the free circulation of knowledge within the very same indigenous community ${ }^{134}$.

In this sense, the misappropriation right, as framed by the WIPO Committee, seems well suited to satisfy both parties' interests because: on the one hand, it does not create a new strong exclusive right against whatever utilization of traditional knowledge by foreign people; but on the other hand, it provides TK-owners with a negative right actionable to prevent third parties from expropriating with no compensation their intangible heritage. This form of entitlement indeed would not condemn the behaviors of third parties that make profits thanks to traditional knowledge as long as its acquisition, appropriation or utilization is not the fruit of illicit or unfair means ${ }^{135}$.

Moreover, such a negative misappropriation right would appear the best possible system to harmonize with - and hence, protect -- local indigenous regimes for TK protection. The former indeed would not require any formalities whatsoever ${ }^{136}$ and would only activate when TK is unlawfully expropriated. Hence, the coexistence of the two regimes would be smooth and peaceful, as there would be no need to compel countries providers of TK to substitute their own indigenous legal regime with the new one.

\subsubsection{Commonalities and differences with the Compensatory Liability Regime}

This misappropriation model has some commonalities with the discussed CLR discussed above $^{137}$. In both cases, indeed, the system would grant TK owners an entitlement which

\footnotetext{
134 See document WIPO/GRTFK/IC/9/5, Annex, p. 17. Think indeed of what would happen if DCs implemented a strong regime of protection for TK and then foreign companies would appropriate, under that regime, all TK even locally.

${ }^{135}$ See supra para. 6.2.

${ }^{136}$ See art. 11 of IGC document, annexed to document WIPO/GRTKF/IC/9/5.

${ }^{137}$ See infra para. 6.2. The misappropriation regime would work, to some extents, like a compensatory system in that it allows third parties to get the TK but, at the same time, it grants TK-owners the right to sue them if such taking has happened through unfair and illicit means.
} 
does not vest TK owners with the power to foreclose access to their knowledge to third parties. Moreover, in both cases access would be permitted in exchange of some form of compensation: but here is where the two systems differ.

As explained above, the CLR substantiate into three distinct faculties: (i) the power to prevent slavish imitation to be put in the market; (ii) the right to obtain reasonable compensation from improvement innovations based on TK; and (iii) the right to obtain and make use of such improvements in order to ameliorate the initial pool of TKs.

Comparing the two systems significant differences do emerge. First of all, the misappropriation regime does not prevent the taking of TK for wholesale imitations. This means that, under the misappropriation system, third parties may well borrow TK to market and commercialize products which directly embed its scientific findings and do not improve on it anyhow. This is obviously conditioned to the circumstance that access is obtained through legal means and TK owners are monetarily compensated ${ }^{138}$.

This difference is of significant importance because many cases exist where foreign companies simply acquire the TK related, for example, to the medicinal properties of a certain plant and simply put on the market its purified extracts. With no protection envisaged for such cases, TK owners would not be able to get the benefits coming from a wider exploitation of their knowledge.

The second and the third faculties granted by the CLR are certainly comprehended within the vast array of faculties granted to TK owners. At this regard, it is worth recalling that among the conduct expressly banned by art. 1, paragraph 3, of the IGC proposed document, there are "false claims or assertion of ownership [...] including acquiring,

\footnotetext{
${ }^{138}$ At this regard, art. 6.1. of the IGC document expressly establishes that the benefits of protection for TK holders include the fair and equitable sharing of benefits arising out of the commercial or industrial use of TK.
} 
claiming or asserting intellectual property rights over traditional knowledge-related subject matter when those intellectual property rights are not validly held in the light of that traditional knowledge and any conditions relating to its access" ${ }^{\prime 139}$; and, once TK has been lawfully accessed, its commercial or industrial use "without just and appropriate compensation $[\ldots]$ when such use has gainful intent and confers a technological or commercial advantage on its use $[\ldots]^{140,}$

Furthermore, art. 6.2 envisages that even when TK has been borrowed and used for noncommercial purposes, TK owners are entitled to a non-monetary benefit in the form of "access to research outcomes and involvement of the source community in research and educational activities".

Eventually, art. 8 of the IGC proposal states that the application and implementation of this model of TK protection should not adversely affect "the continued availability of traditional knowledge for the customary practices, exchange, use and transmission of TK by TK holders.

At this regard, and in order to better harmonize the misappropriation regime and $\mathrm{TK}$ interests with existing IP regimes, the IGC could think about inserting a more express provision envisaging an exception, in favor of TK holders, to the exclusive patent rights on an invention based on TK. The provision, for example, should establish that the exclusive right granted to a patentee should not be opposable to TK holders whose knowledge has permitted the creation of the invention.

\footnotetext{
${ }^{139}$ See art. 1.3(iii) of IGC document, annexed to document WIPO/GRTKF/IC/9/5.

${ }^{140}$ See art. 1.3(iv) of IGC document, annexed to document WIPO/GRTKF/IC/9/5.
} 


\subsubsection{Implementation measures and legal status of the misappropriation regime}

It might be argued that a misappropriation regime carries the risk that each single country applies the provision differently, affording a broader or smaller scope of protection according to the degree of protection locally afforded by their national misappropriation statutes. At this regard, it is important to mention that in some countries, like for example, the United States of America, misappropriation doctrine has a narrow scope of protection.

This risk should be quite narrow because, as hinted above, the Committee's document contains, together with a general definition of what can amount to a misappropriation of TK, a comprehensive list of conduct that result in a misappropriation or misuse of TK.

Therefore, the effectiveness of the adoption of this peculiar form of misappropriation regime hinges on the legal status the Committee will eventually choose and the implementation mechanism. At this regard, however, the IGC proposal leaves open the issue of how the misappropriation regime should be implemented nationally, saying that there is a whole set of legal measures ranging from a special law on tradition knowledge, intellectual property laws, law of civil liability, ad hoc laws concerning the interests of indigenous people and so on ${ }^{141}$.

In other words, the document drafted by the Committee would simply set some international standards national countries are free to implement ${ }^{142}$.

\footnotetext{
${ }^{141}$. See art. 2 of the IGC document, annexed to document WIPO/GRTKF/IC/9/5.

${ }^{142}$ For the sake of preciseness, the document does not even exclude the possibility that local governments decide to implement the international standards in the form of exclusive property rights; although this possibility seems available only for individual and collective holders of TK. See art. 2.1. of the ICG document, annexed to document WIPO/GRTKF/IC/9/5.
} 
The document only envisages a flexible form of national treatment principle whereby foreign TK holders should be entitled protection against misappropriation and misuse of their TK, provided that they are located in a country which is considered eligible ${ }^{143}$.

National treatment, however, can be a loose standard if countries are allowed to implement discretionally the regime outlined above because such principle would simply afford foreign TK holders a treatment that is at least as favorable as the treatment the country at issue would grant to its own TK holders. However, if the country decides to grant to its own residents a low degree of protection -- maybe because it is a Developed and not a Developing country - then TK holders would not receive sufficient protection $\operatorname{abroad}^{144}$.

Eventually, while the third substantive part of the IGC document is the most controversial and difficult to find consensus on, it is extremely important that negotiating parties find an agreement to make its provisions, all of them, compulsory to enact. Accordingly, while some freedom should be allowed to participating countries, such as the possibility to envision further behaviors that amount to misappropriation of $\mathrm{TK}$, it should be compelling that all countries punish these acts listed on art. 1, paragraph 3, and that all countries enact a system whereby not only monetary compensation is provided for the simple taking of TK resources, but also that allow TK holders to benefit from foreign researches based on their TK.

\footnotetext{
${ }^{143}$ Art. 14 of the IGC document establishes that "[...] these international standards should be available to all eligible traditional knowledge holders, who national or habitual resident of a prescribed country as defined by international obligations or undertakings. Eligible foreign holders of TK should enjoy the benefits of protection to at least the same level as traditional knowledge holders who are nationals of the country of protection $[\ldots] "$.

${ }^{144}$ It is worth recalling that often the TK stolen from its owners is implemented to market products that are almost exclusively sold in Developed Countries' markets therefore it is extremely important that TKowners are recognized protection abroad.
} 


\subsection{Traditional knowledge and open source, why not?}

The second alleged barrier for granting TK-owners protection for their intangible "property" regarded the cumulative and incremental process which gives birth to indigenous scientific culture.

At a closer look, however, it might be pointed out that these features are not so distant from today's innovative process in industrialized countries which shows a rather sequential and cumulative character. And in fact, even in Developed Countries the figure of the single innovator has almost vanished and it has been replaced by research teams where a group of people working all together, day by day, bring about negligible steps, “slivers of innovation" (which, unfortunately, come under patent protection) ${ }^{145}$.

The collective and cumulative model of TK creation resembles, even more closely, the so called viral effect underlying open source software (OSS), whose licensing mechanism allows people to enter the pool of common knowledge and elaborate upon it, provided that they grant similar access to the dependent innovation, hence bringing the derivative knowledge back to the pool ${ }^{146}$.

OSS works thanks to the fictitious stretch of copyright subject matter to cover, mainly, sub-patentable inventions. Copyright law today, in practice, affords almost no protection at all to software but it proves successful in granting programmers entitlements to the know-how embedded in their innovations. Thanks to this modicum of protection,

\footnotetext{
${ }^{145}$ Many eminent scholars agree on this point. See, among them, J.H. Reichman, Saving the Patent System from Itself, Informal Remarks Concerning the Systemic Problems Afflicting Developed Intellectual Property Regimes (2003) in Perspectives on Properties of the Human Genome Project, edited by F.S. Kieff, Elsevier Academic Press, Oxford, (2003), 289; J. H. Reichman \& T. Lewis, Using Liability Rules to Stimulate Local Innovation: Application to Traditional Knowledge, in INTERNATIONAL PUBLIC Goods And Transfer Of Technology Under A Globalized Intellectual Property Regime, edited by J.H. Reichman and K. Maskus, Cambridge MA, 2005.

${ }^{146}$ On open source software in general see S. Dusollier, Open Source and Copyleft: Authorship Reconsidered? 26 COLUM. L.J. \&. ARTS 281 (2003).
} 
programmers are able to create and share a common pool of resources which they all come to advance with mutual effort but also common enjoyment.

While the choice of copyright paradigm to protect a utilitarian subject matter like software is questionable ${ }^{147}$, it cannot be doubted that a licensing scheme based on the recognition of a limited entitlement has brought great results for innovation in the software industry.

A misappropriation regime like the one shaped above, which only provides a negative right towards the protection of intangible knowledge and that provides for both monetary compensation as well as access to the fruit of foreign research based on TK, would be capable of bringing about the same beneficial properties of the OSS. In fact, it would allow TK holders to benefit at large from their knowledge in the form of both monetary compensation and advancement of the very same knowledge.

\subsection{Misappropriation right and the anticommons over genetic resources}

It has been critically pointed out that a potentially infinite ${ }^{148}$ sui generis right like the one shaped by the WIPO Committee would have the ultimate effect of bolstering the formation of anticommons over the genetic resources owned by indigenous communities mainly located in Developing Countries ${ }^{149}$.

\footnotetext{
${ }^{147}$ G. Ghidini \& E. Arezzo, Patent and copyright paradigms vis-à-vis derivative innovation: the case of computer programs, in IIC, n.2, 2005, p.159.

${ }^{148}$ Recall, indeed, that the proposal requires the protection to last as long as the requirement listed in art. 4 are complied with. See supra note 75.

${ }^{149}$ Koopman says: "The proprietary regime for traditional knowledge envisaged by WIPO applies to knowledge that may solely a resource, and is not yet "applied" in any way". J. Koopman, Bumps and Bends in the Road to Intellectual Property for Traditional Knowledge, at 274 and ff.
} 
As well known, the term anticommons has been introduced by Heller to refer to the situation opposite to the so called tragedy of the commons. ${ }^{150}$ The tragedy of the anticommons would indeed occur when too many (often overlapping) rights have been granted over certain scarce resources and this ends up impeding each entitled party to fully exploit her property due to the huge transaction costs she would need to face for whatever use of her good.

Could it be possible that a negative right like the one proposed by WIPO would enable local communities to privatize their intangible scientific heritage and impede access to foreign firms ${ }^{151}$

As already explained, the misappropriation right would not vest traditional knowledge owners with the right to prevent others from having access to their intangible "property". Rather, it should function as a mechanism to defend TK-owners when neither access nor compensation has been negotiated with them.

The time issue might probably raise some eyebrows, but it needs be reminded that the misappropriation right, as shaped by WIPO, has its closest model in unfair competition laws rather than intellectual property paradigms. As unfair competition laws generally do, the model suggested would afford a lesser degree of protection in terms of exclusive and excluding powers; and like unfair competition laws, whose principles are strongly

\footnotetext{
${ }^{150}$ M.A. Heller, The Tragedy of the Anticommons: Property in the Transition from Marx to Markets, in 111 HARV. L. REV. 621, 1998.

${ }^{151}$ Note that the problem has been misconstrued from the beginning. The anticommons issue refers to a situation where many parties have been granted overlapping rights over (maybe different aspects/functions of) the same resources so that if each of them want to use her bit, she needs to clear her property from others' rights. In the case of traditional knowledge this would not happen. Even if indigenous communities were granted a strong exclusive right - which is not what has been envisioned by WIPO - there would be no overlapping rights. Moreover, the anticommons problem refers to a situation where owners of the rights have to negotiate between themselves. This, again, would not be the case for traditional knowledge where indigenous communities - the only and exclusive holders of their intangible knowledge - would have to negotiate with foreign firms.
} 
connected with a sense of natural justice and fairness, such form of protection exists as long as there are interests to protect ${ }^{152}$.

Quite on the contrary, the anti-commons problem is going to occur very soon if the phenomenon of "bad patenting" is not stopped. If modern patent laws are not amended in such a way to include widespread traditional knowledge within novelty and nonobviousness inquiries, there is a substantive risk that more and more exclusive rights will be granted over each tiny bit of knowledge, with the ultimate effect that the very same indigenous communities will be prevented, with no compensation, to keep using their own scientific heritage.

\section{Conclusion}

This study aimed at analyzing the issues stemming from the widespread misappropriation of biodiversity and traditional knowledge, owned by indigenous people and local communities, by Developed Countries' companies. I purposely framed the issue in terms of misappropriation because, even in cases where a negotiation takes place, the unequal bargaining strength of the parties often leads to biased agreements where indigenous people are usually compensated for the use of their tangible resources but not for the taking of related $\mathrm{TK}$.

As explained at the very beginning of this work, a normative international framework has been established in 1992 but for several reasons - one of them its status outside WTO

\footnotetext{
${ }^{152}$ Besides, from a pure IP perspective, it could be further argued that many legislative moves have been recently advanced to stretch copyright law far beyond its initial time limits. I refer not simply to the increasing of time length due to the Sonny Bono Copyright Extension Act but also to the introduction of the anticircumvention measures contained in the DMCA which allows for an infinite entrapment of both copyrighted and not-copyrighted material (think indeed about derivative works from a previous work lying in the public domain; the protection through technological fences would foreclose access also to the portion of the work pertaining to the society).
} 
negotiations - this set of rules has proven to be inadequate or, at least, insufficient to deal with the problem.

As time passed the biopiracy issue attracted more and more consideration and several proposals have been advanced simultaneously in different international fora. Many (often Developing) Countries have seen a likely solution of the problem in the amendment of national patent laws in such a way to compel future patent applicants to disclose the source of origin of the genetic material and TK utilized in their invention. Because it is very complex, time-consuming and expensive for indigenous people to screen patent applications and (granted) patents to find out when their tangible or intangible properties have been stolen, such measure has been deemed useful in that it could surely facilitate this task.

This proposal has attracted strong criticism from United States and Japan who assert that the legal measures that would arise when patentees fail to comply with this requirement would hamper patent law's stability and certainty, with enormous consequences for economic progress as a whole.

Conversely, this measure alone would not be sufficient to solve the outlined problem. In particular, even if such measures would be adopted, and indigenous people would indeed be able to discover which patents have misappropriated their property, there is no chance that they would then get a proper compensation pursuant to CBD's principles. This is because many patent laws have very protectionist provisions regarding novelty (in particular anticipation) and non-obviousness which neglect to take into account traditional knowledge when pursuing such inquiries. 
Given the mobility of foreign biologists and researchers and the widespread reach of the internet as a carrier of information, it would be desirable to have TK considered as prior art, capable to anticipate a patent as well as a piece of knowledge forming the so called state of the art.

However, such changes, by themselves would only achieve half of the goal outlined by the CBD. In fact, CBD provisions want indigenous people both to benefit from third parties' exploitation of their resources and to have access to the results of third parties' investments and researches on their inputs; the benefits envisaged by the CBD indeed extend to the possibility to have access and obtain both monetary and non-monetary benefits from whatever utilization of the goods produced thanks to their resources.

The amendments of national patent laws could enable TK-owners to get only the first kind of benefits described above. In order for them to participate in the benefits flowing from the exploitation of subsequent innovations based on their own TK and biodiversity, they need to have some sort of legal entitlement. Given the nature of TK that is somewhat in the middle between scientific know-how and inventions, depending from case to case, it seems appropriate to confer TK-owners an entitlement that is less stringent than a true exclusive right, but that it suffices to entitle them to prevent the illicit misuse and misappropriation of their intangible knowledge.

In conclusion, TK-owners would greatly benefit from the adoption of a misappropriation regime modeled on a liability rule scheme like the one framed by WIPO Intergovernmental Committee on Intellectual Property and Genetic Resources, Traditional Knowledge and Folklore. 
The adoption of such a regime by Developed Countries would grant TK-owners the right to sue for misappropriation not only whoever took the intangible resources through unfair conducts but also whoever derives a commercial benefit from such acquisition, appropriation or utilization when she should have known that such resources were acquired through unfair means. Therefore, the way the misappropriation right has been shaped seems to complement the safeguards provided by the aforementioned suggested amendments to national patent laws, especially America's, because it seems to protect indigenous people also from the second type of benefits, namely the sharing of the benefits flowing from subsequent application or implementation of indigenous TK.

However, because the problem this study was meant to solve was biopiracy relating to genetic resources and TK, and because biopiracy acts are pursued by companies located in rich Developed Countries who then exploit such resources mainly in their own markets, it is crucial that the latter be compelled to adopt the new legal measures. To this purpose, it is of crucial importance that the IGC works hard to find mutual consensus on the substantive provisions examined above and on a legal international status of such provisions, in such a way that they be substantially implemented by all member states, especially Developed Countries.

As explained supra, this is fundamental because the misappropriation doctrine has different scope of application in each country and a simple implementation of the principle that TK and the misappropriation of genetic resources be protected through national misappropriation regimes might not be sufficient in granting TK holders enough protection in foreign countries. 